\title{
Vermiculite:
}

\section{Structural Properties and Examples of the Use}

\author{
Marta Valášková and Gražyna Simha Martynková
}

Additional information is available at the end of the chapter

http://dx.doi.org/10.5772/51237

\section{Introduction}

The effort to clarify the meanings of the terms 'clay', 'clays', and 'clay minerals' was the subject of the joint nomenclature committees (JNCs) of the Association Internationale pour l'Etude des Argiles (AIPEA) and the Clay Minerals Society (CMS). The JNCs have proposed the term a class of hydrated phyllosilicates forming the fine-grained fraction of rocks, sediments, and soils and have defined 'clay' as "a naturally occurring material composed primarily of fine-grained minerals, which is generally plastic at appropriate water contents and will harden when dried or fired" [1]. According to this definition synthetic clays and clay-like materials are not regarded as clay even though they may be fine grained, and display the attributes of plasticity and hardening on drying and firing.

For phyllosilicates, the terms "planes", "sheet" and "layer" refer to specific parts of the structure, with atomic arrangements that increase in thickness and they cannot be used interchangeably $[2,3]$.

A 'plane' can occur consisting of one or more types of atoms (e.g. a plane of Si and Al atoms, a plane of basal oxygen atoms).

A 'tetrahedral sheet' is composed of continuous corner-sharing tetrahedra like 'octahedral sheet' is composed of the edge-sharing octahedra.

A 'layer' contains one or more tetrahedral sheets and an octahedral sheet.

'Interlayer material' separates the layers and generally may consist of cations, hydrated cations, organic materials, and/or hydroxide octahedral sheets. In certain cases (e.g. talc, pyrophyllite) there is no interlayer material, and thus an empty interlayer separates the layers. 
Layer charge ( $x$ ) per half unit cell (p.f.u.), is the net negative charge per layer, expressed as a positive number (eq/(Si,Al) $\left.)_{4} 0_{10}\right)$. The net negative layer charge arises from substitution of $\mathrm{Al}^{3+}$ for $\mathrm{Si}^{4+}$ in tetrahedra and substitution for lower charge cations in octahedra and from the presence of vacancies. The negative layer charge is balanced by the positively charged interlayer material.

A 'unit structure' is the total assembly and includes the layer and interlayer material. Therefore it is inappropriate to refer to a 'tetrahedral layer' or an 'octahedral layer', although these incorrect terms are commonly found in the literature.

Guggenheim et al [4] give the revised classification scheme for planar hydrous phyllosilicates [5].

The phyllosilicates are divided by layer type, and within the layer type, and by groups based on charge p.f.u. Further subdivisions by subgroups is based on dioctahedral or trioctahedral character, and finally by species based on chemical composition. Two types of layers, depending on the component sheets are a '1:1 layer' consisting of one tetrahedral sheet and one octahedral sheet, and a '2:1 layer' containing an octahedral sheet between two opposing tetrahedral sheets.

The structure of 2:1 phyllosilicates is composed of tetrahedral $(\mathrm{T})$ and octahedral $(\mathrm{O})$ sheets (Fig. 1). According to the AIPEA Nomenclature Committee [4], tetrahedral sheet is composed of continuous two-dimensional corner-sharing tetrahedra $\left[\mathrm{TO}_{4}\right]^{4-}$ involving three basal oxygens and the apical oxygen. The tetrahedral sheet has a composition of $\left[\mathrm{T}_{4} \mathrm{O}_{10}\right]^{4-}$ where $\mathrm{T}=\mathrm{Si}^{4+}, \mathrm{Al}^{3+}$, $\mathrm{Fe}^{3+}$. The apical oxygens form a corner of the octahedral coordination unit around larger octahedral cations. The octahedral sheet consists of two planes of closely packed $\mathrm{O}^{2-}, \mathrm{OH}^{-}$anions of octahedra with the central cations $\mathrm{Mg}^{2+}$ or $\mathrm{Al}^{3+}$. The smallest structural unit contains three octahedral sites. The trioctahedral structures of phyllosilicates have all three sites occupied with cations (e.g. hydroxide sheet $\left.\mathrm{Mg}_{6}(\mathrm{OH})_{12}^{12-}\right)$. The dioctahedral phyllosilicates have two octahedral sites occupied with cations (e.g. hydroxide sheet, $\mathrm{Al}_{4}(\mathrm{OH})_{12}^{12-}$ ) and one site is vacant.

Smectites are 2:1 phyllosilicates with a total (negative) layer charge between 0.2 and 0.6 p.f.u.. The octahedral sheet may either be dominantly occupied by trivalent cations (dioctahedral smectites) or divalent cations (trioctahedral smectites).

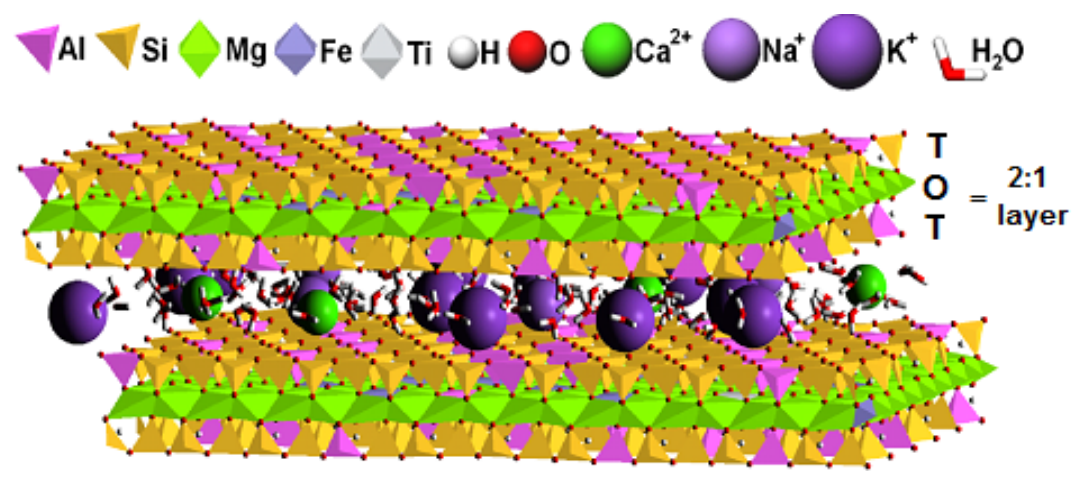

Figure 1. Model of the structure of vermiculite from Brazil; (with courtesy of dr. Jonáš Tokarský). 
Vermiculites are generally trioctahedral and are termed (according to the joint nomenclature committees AIPEA and CMS) on the basis of a negative layer charge, which is between 0.6 to 0.9 p.f.u. $[4,7,8]$. The negative layer charge of vermiculites results from the substitution of $\mathrm{Si}^{4+}$ by trivalent cations in tetrahedral positions $[9,10]$. Vermiculites were mostly formed by removal of potassium from biotite, phlogopite or muscovite $[5,6]$ and therefore vermiculite chemistry from this perspective is closely linked to that of mica. The thickness of the structural unit (2:1 layer and interlayer space) is about $1.4 \mathrm{~nm}$, depending on the water interlamellar layers and the interlayer cations. Bailey [9] and Lagaly [10] described a method to determine the layer charge based on the measurement of basal spacings after exchange with alkylammonium cations of varying chain lengths. Alkylammonium ions in the interlayer spaces of vermiculite acquire distinct arrangements: monolayer and two-layer (bilayer) structures with the alkyl chains parallel to the surface, pseudotrimolecular layers and paraffin type structures. Vermiculites have paraffin-type interlayers if the layer charge is at least 0.75 p.f.u.

The identification of trioctahedral and dioctahedral vermiculites is based on the position of reflection (060) on their XRD patterns. Dioctahedral vermiculites show an interlayer space value $d(060)$ between $0.149 \mathrm{~nm}$ and $0.150 \mathrm{~nm}$, while trioctahedral vermiculites have $d(060)$ between $0.151 \mathrm{~nm}$ and $0.153 \mathrm{~nm}[11]$.

The cation exchange capacity (CEC) of clay minerals is defined as "the quantity of cations available for exchange at a given $\mathrm{pH}$ expressed in meq/100g which is equivalent to $\mathrm{cmol}(+) / \mathrm{kg}$ [13]. The CEC varies between the 120 and $200 \mathrm{cmol}+/ \mathrm{kg}$ (air dried vermiculites) or 140 and $240 \mathrm{cmol}(+) / \mathrm{kg}$ (dehydrated vermiculites) [14,15]. Water molecules associated with internal surfaces evokes hydration of interlayer cations. The total amount of alkylammonium ions bound by 2:1 clay minerals is often slightly higher than the total CEC determined by other methods [16]. This is a consequence of the charge regulation at the edges. Density of the charges at the crystal edges depend on the $\mathrm{pH}$ of the dispersion and arises from adsorption or dissociation of protons. In an acidic medium an excess of protons creates positive edge charges, the density of which decreases with rising $\mathrm{pH}$. Negative charges are produced by the dissociation of silanol and aluminol groups $[17,18]$.

Vermiculite structures contain water interlamellar layers which are subjected to the hydration and dehydration processes [19-26]. The hydration properties are controlled by the interlayer cations $\mathrm{Mg}^{2+}$ and minor amounts of $\mathrm{Ca}^{2+}, \mathrm{Na}^{+}$, and $\mathrm{K}^{+}$. The cation radius and charge influence the degree of hydration state in the interlayer and the stacking layer sequences $[9,15,19,22,28]$. The hydration state of vermiculite was defined by the number of water layers in the interlayer space. The basal space of Mg-vermiculite was declared 0.902 $\mathrm{nm}$ for zero-water layer, $1.150 \mathrm{~nm}$ for one-water layer and $1.440 \mathrm{~nm}$ for two water layer hydration state [29].

Ordering in vermiculite layered structure occurs when the pseudohexagonal cavities (made of six-membered tetrahedra rings) are facing each other in adjacent tetrahedral layers. In most cases the vermiculites have various possible layer-stacking sequences and therefore the regular arrangement of the layers in vermiculites occurs rarely [30-33]. 
Criteria for defining the degree of regularity of alternation of different layer types (e.g. 1:1 or 2:1 layers) were recommended in criteria for interstratification nomenclatures $[4,12]$.

The structure of vermiculite is called semi-ordered when the transition from a layer to the next layer can be obtained in two or more different ways. For semi-ordered stacks the reciprocal space cannot be described by a set of $h k l$ indexes but rather by modulated reciprocal $h k$ with the variable intensity along them [15]. The regular alterations of 1.150 and $0.902 \mathrm{~nm}$ domains can create the regular interstratification with $d=2.060 \mathrm{~nm}$. Collins et al. [21] studied the variability in $d$ values of the basal spacings of vermiculite from Llano (Texas). Authors assigned interlayer values $d=1.04-1.03 \mathrm{~nm}$ to the interstratified one-zero layer hydrate and the value $d=1.28 \mathrm{~nm}$ as random interstratified phase of two- and onelayer hydrates. The X-ray diffraction patterns of the South African raw vermiculite with high potassium content in the interlayer space $\left(K_{0.53}\right)$ showed the value $d=1.45 \mathrm{~nm}$ corresponding to the vermiculite and additional peaks with $d=2.52 \mathrm{~nm}, d=1.26$ and 1.205 $\mathrm{nm}$, which were attributed to a biotite-vermiculite mixed-layer mineral [34]. Reichenbach and Beyer [22] evaluated two superstructures formed by a regular 1:1 interstratification. One of them with $d=2.541 \mathrm{~nm}$ as a result of the altering layers with $d=1.376$ and $1.165 \mathrm{~nm}$. Other superstructure with the value $d=2.153 \mathrm{~nm}$ was assigned to the altering layers $1.151 \mathrm{~nm}$ and $1.002 \mathrm{~nm}$. The hydrated states and interstratified phases in the vermiculites from Sta. Olalla (Spain), Paulistana (Brazil), Palabora (South Africa) and West China described Marcos et al. [25, 26]. Authors came to the founding that vermiculite from China consists of alternating mica layers ( $d=1.02 \mathrm{~nm}$, zero-water layer hydration) with vermiculite layers ( $d=1.47 \mathrm{~nm}$, two-water layer hydration) and two-one layer hydration interstratification with $d=1.21 \mathrm{~nm}$.

The structural formula of vermiculites is often reported on the basis of the structure unit (half unit-cell content). The general formula can be written as:

$\mathrm{X}_{4}\left(\mathrm{Y}_{2-3}\right) \mathrm{O}_{10}(\mathrm{OH})_{2} \mathrm{M}$. $n \mathrm{H}_{2} \mathrm{O}$,

where $\mathrm{M}$ is exchangeable $\left(\mathrm{Mg}^{2+}, \mathrm{Ca}^{2+}, \mathrm{Ba}^{2+}, \mathrm{Na}^{+}, \mathrm{K}^{+}\right)$cations positioned in the interlayer space, that compensate negative layer charge, $\mathrm{Y}$ is octahedral $\mathrm{Mg}^{2+}, \mathrm{Fe}^{2+}$ or $\mathrm{Fe}^{3+}, \mathrm{Al}^{3+}$, and $\mathrm{X}$ is tetrahedral Si, Al.

The half unit cell compositions of vermiculites given in literature are listed below for comparison.

(Si2.86 $\left.\mathrm{Al}_{1.14}\right)\left(\mathrm{Mg}_{2.83} \mathrm{Al}_{0.15} \mathrm{Fe}^{3+}{ }_{0.02}\right) \mathrm{O}_{10}(\mathrm{OH})_{2} \mathrm{Mg}_{0.41} \cdot 3.72 \mathrm{H}_{2} \mathrm{O}$ (Llano), [9]

(Si2.72 $\left.\mathrm{Al}_{1.28}\right)\left(\mathrm{Mg}_{2.36} \mathrm{Al}_{0.16} \mathrm{Fe}_{0.58}\right) \mathrm{O}_{10}(\mathrm{OH})_{2} \mathrm{Mg}_{0.32} \cdot 4.32 \mathrm{H}_{2} \mathrm{O}$ (Kenya), [19]

$\left(\mathrm{Si}_{2.72} \mathrm{Al} 1.28\right)\left(\mathrm{Mg}_{2.59 \mathrm{Fe}^{2+}}{ }_{0.03} \mathrm{Al}_{0.06} \mathrm{Fe}^{3+}{ }_{0.24} \mathrm{Ti} 0.08\right) \mathrm{O}_{10}(\mathrm{OH})_{2} \mathrm{Mg}_{0.39} \mathrm{Ca} 0.02 \cdot 4.7 \mathrm{H}_{2} \mathrm{O}$ (Santa Olalla, Spain), [15]

(Si2.64 $\left.\mathrm{Al}_{1.36}\right)\left(\mathrm{Mg}_{2.48} \mathrm{Fe}^{2+}{ }_{0.04} \mathrm{Al}_{0.14} \mathrm{Fe}^{3+}{ }_{0.32} \mathrm{Ti}_{0.01} \mathrm{Mn}_{0.01}\right) \mathrm{O}_{10}(\mathrm{OH})_{2} \mathrm{Mg}_{0.44}$ (Santa Olalla, Spain), [35]

(Si2.69 $\left.\mathrm{Al}_{1.31}\right)\left(\mathrm{Mg}_{2.48} \mathrm{Fe}^{3+}{ }_{0.324} \mathrm{Fe}^{2+}{ }_{0.036} \mathrm{Al}_{0.14} \mathrm{Ti}_{0.01} \mathrm{Mn} 0.01\right) \mathrm{O}{ }_{10}(\mathrm{OH})_{2} \mathrm{Mg}_{0.39}$, (Santa Olalla, Spain), [57] 
(Si2.83 $\left.\mathrm{Al}_{1.17}\right)\left(\mathrm{Mg}_{2.01} \mathrm{Al}_{0.2} \mathrm{Fe}^{2+}{ }_{0.16} \mathrm{Fe}^{3+}{ }_{0.40} \mathrm{Ti}_{0.14}\right) \mathrm{O}_{10}(\mathrm{OH})_{2} \mathrm{Mg}_{0.235}$ (Ojen, Spain), [35]

$\left(\mathrm{Si}_{2.83} \mathrm{Al}_{1.17}\right)\left(\mathrm{Mg}_{2.01} \mathrm{Fe}^{3+}{ }_{0.4} \mathrm{Fe}^{2+}{ }_{0.16} \mathrm{Al}_{0.2} \mathrm{Ti}_{0.12}\right) \mathrm{O}_{10}(\mathrm{OH})_{2} \mathrm{Mg}_{0.275}$ (Ojen, Spain), [57]

$\left(\mathrm{Si}_{2.64} \mathrm{Al}_{1.36}\right)\left(\mathrm{Mg}_{2.38} \mathrm{Fe}^{2+}{ }_{0.02} \mathrm{Al}_{0.06} \mathrm{Fe}^{3+}{ }_{0.51} \mathrm{Ti}_{0.03}\right) \mathrm{O}_{10}(\mathrm{OH})_{2} \mathrm{Mg}_{0.35} \mathrm{Ca} .01 \mathrm{Na}{ }_{0.01} \cdot 4.9 \mathrm{H}_{2} \mathrm{O}$ (Letovice, Czech Republic), [28].

(Si3.02 $\left.\mathrm{Al}_{0.98}\right)\left(\mathrm{Mg}_{2.27} \mathrm{Al}_{0.12} \mathrm{Fe}^{3+}{ }_{0.28} \mathrm{Fe}^{2+}{ }_{0.05} \mathrm{Ti}_{0.07}\right) \mathrm{O}_{10}(\mathrm{OH})_{2} \mathrm{Ca}_{0.09} \mathrm{Na}_{0.21} \mathrm{~K}_{0.50}$ (West China), [36].

$\left(\mathrm{Si}_{3.02} \mathrm{Al}_{0.79} \mathrm{Ti}_{0.05} \mathrm{Fe}^{3+}{ }_{0.14}\right)\left(\mathrm{Mg}_{2.50} \mathrm{Fe}^{2+}{ }_{0.38} \mathrm{Fe}^{3+}{ }_{0.09}\right) \mathrm{O}_{10}(\mathrm{OH}, \mathrm{F})_{2} \mathrm{Ba} 0.29 \mathrm{~K}_{0.14} \mathrm{Ca} 0.08$ (Palabora, South Africa), [37].

(Si3.43 $\left.\mathrm{Al}_{0.57}\right)\left(\mathrm{Al}_{0.26} \mathrm{Fe}_{0.32} \mathrm{Mg}_{2.34}\right) \mathrm{O}_{10}(\mathrm{OH})_{2} \mathrm{Ca} 0.064 \mathrm{Na} 0.016 \mathrm{~K}_{0.047}$ (Brazil), [38].

\section{Obtaining vermiculite small particles}

Natural vermiculite flakes are characterized by high values of aspect ratio. In clay science, exfoliation involves a degree of separation of the layers of a host structure where units, either individual layers or stacking of several layers, are dispersed (freely oriented and independent) in a solvent or polymer matrix [39]. This may be achieved by intercalation, by mechanical procedures, or by other methods. Exfoliation implies that the orientation between the layers of the host structure is lost, and that interlayer cohesive forces are overcome. If delamination or exfoliation cannot be distinguished, the terms "intercalation" or "delamination/exfoliation" should be use [40].

Delamination is a term used to describe a layer-separation process between the planar faces of adjacent layers of a particle. Delamination describes a process where intercalation occurs: guest material introduces between the layers while the stacking of layers remains. When delamination cannot be distinguished from exfoliation, the terms "intercalation" or "delamination/exfoliation" should be use to describe the process [40].

Intercalation is a general term to describe the movement of atoms, ions or molecules into a layered host structure, often a swelling clay mineral. The resulting structure is an "intercalated structure" [40].

Exfoliated vermiculite can be produced either by a thermal or a chemical treatment. Heating a particle of vermiculite rapidly above about $200{ }^{\circ} \mathrm{C}$ results in the transformation of the interlayer water into steam. The thermal shock is the best-known procedure for dissociating the macroscopic packet of vermiculite [41]. The pressure of the steam separates silicate layers to the several orders thicker than were the fundamental layers. Such exfoliated particles exhibit the "accordion" type morphology. The large thermal expansion of the vermiculite after explosive dehydration of interlayer water causes cracking of vermiculite flakes. This exfoliation generates a 10 to 20 times volume expansion but the basal dimensions of the particles are unchanged [42]. This exfoliation is associated with a sudden release of water molecules between the silicate layers and also the hydroxyl water gradually releasing on heating from about 500 to $850^{\circ} \mathrm{C}$ [44]. The water rapidly vaporized cause a disruptive effect upon the particles, in industry called exfoliation. Several authors have 
found that the presence of the mixed-layer vermiculite-mica or mixed-layer minerals phases containing vermiculite in different hydration states contributed to the exfoliation of vermiculites $[26,45,46]$.

Preparation of submicron-sized vermiculites is usually accomplished by applying wet and dry grinding [47].

Progressive amorphization and agglomeration of vermiculite particles takes place when grinding time increases [48].

Vermiculite can be also delaminated using the mechanical shearing force $[49,50]$.

Balek et al.[51] found that vermiculite from Santa Olalla after grinding for 2 min increased specific surface area from $1 \mathrm{~m}^{2} \mathrm{~g}^{-1}$ to $39 \mathrm{~m}^{2} \mathrm{~g}^{-1}$. Prolongation of grinding time to $10 \mathrm{~min}$ led to the formation of amorphous phase and the surface area decrease to $20 \mathrm{~m}^{2} \mathrm{~g}^{-1}$. The thermogravimetry measurement recorded different thermal behavior of original and milled vermiculite samples. Original vermiculite showed two dehydration steps after heating up to $250^{\circ} \mathrm{C}$ and one dehydroxylation step at $900^{\circ} \mathrm{C}$. The grounded sample showed no such steps but dehydration was observed as continuous mass loss from 50 to $350^{\circ} \mathrm{C}$ and dehydroxylation was completed at $800^{\circ} \mathrm{C}$.

Ultrasound is an alternative method for reduction of the particle size using treatment by high power. The ultrasound caused delamination and particle size reduction not only along the basal planes but also in different directions [52-55]. Péréz-Maqueda et al. [56] compared vermiculites after the grinding and ultrasonic treatments. According to authors, the sonication resulted in particle size reduction and particles retained the plate-like morphology of the original vermiculite. The prolonged grinding caused the loss of longrange order, crystallinity and agglomeration of the particles. The edges of vermiculite particles were changed and allowed easier access nitrogen during measurements and therefore yielding surface areas larger than those expected only from the particle size reduction. The ultrasound on the high-and low-charge vermiculites studied also Wiewiora et al. [35]. A high-charge vermiculite from Santa Olalla (0.88 p.f.u.) preserved the flake shape, whereas the low-charge vermiculite from Ojén ( 0.47 p.f.u.) displayed scrolling of the flakes into tubes. Sonication differently influenced the specific surface area and increased from the $1 \mathrm{~m}^{2} \mathrm{~g}^{-1}$ at the raw samples to 36 and $54 \mathrm{~m}^{2} \mathrm{~g}^{-1}$ at high-charged and low-charged vermiculites, respectively.

The particle size reduction by sonication may be accompanied by a change of the redox state and the layer charge of the material. Sonication in a 1:1 mixture (volume ratio) of water and hydrogen peroxide $\left(30 \% \mathrm{H}_{2} \mathrm{O}_{2}\right)$ is a soft method for particle size reduction of phyllosilicate minerals like vermiculites [57]. The oxidation state of the iron in the high-charge vermiculite from Santa Olalla and the low-charge vermiculite from Ojén was found different. In spite that the chemical composition of vermiculites is similar (see unit half cell composition formulas), the layer charge is different 0.78 and 0.52 p.f.u. for the Santa Olalla and Ojén vermiculite, respectively. Both of the original vermiculites had the specific surface area 1 $\mathrm{m}^{2} \mathrm{~g}^{-1}$. The area in Ojén-vermiculite increased to $51 \mathrm{~m}^{2} \mathrm{~g}^{-1}$ after eight cycles of sonication in 
water and after the same numer of sonication cycles in an aqueous $15 \% \mathrm{H}_{2} \mathrm{O}_{2}$ to $54 \mathrm{~m}^{2} \mathrm{~g}^{-1}$. The surface area of the Santa Olalla vermiculite after six cycles of sonication was smaller and decreased to the $36 \mathrm{~m}^{2} \mathrm{~g}^{-1}$ after sonication in hydrogen peroxide and $38 \mathrm{~m}^{2} \mathrm{~g}^{-1}$ in water. In both vermiculites, one cycle of sonication provided by half greater value increase in the surface area in water in comparison with sonication in hydrogen peroxide. This difference disappeared after three cycles of sonication. Authors stated that delamination by sonication plays a significant role in particle size reduction and in the increase of the surface areas only after a short time. The $\mathrm{pH}$ during sonication in water 6.5 increased after three cycles to $7.5-8$ and in hydrogen peroxide from 3.7 to 6.5. After sonication no structural change in Santa Olalla vermiculite was observed in comparison with the Ojén-vermiculite. Whereas the ratio $\mathrm{Fe}^{3+} / \mathrm{Fetotal}_{\text {was }}$ found almost constant in the Santa Olalla vermiculite, it increased from 0.79 to 0.85 in case of the Ojén sample together with a decrease of the layer charge.

A strong hydrogen peroxide concentration (up to $50 \%$ ) for exfoliation vermiculite was used by Obut and Girgin [58] and Üçgül and Girgin [59]. Authors interpreted the exfoliation mechanism by a hydrogen peroxide penetration into the interlayer spaces and its decomposition with evolution of atomic oxygen. These interactions disrupt the electrostatic equilibrium between the layers and the interlayer cations. Weiss et al. [60] studied exfoliation of Mg-vermiculite after thermal, microwave and/or hydrogen peroxide treatments. A stronger than hydrogen peroxide oxidation agent potassium persulfate $\left(\mathrm{K}_{2} \mathrm{~S}_{2} \mathrm{O}_{8}\right)$ used Matějka et al. [61] to delaminate/exfoliate Mg-vermiculite. The vermiculite treatment with potassium persulfate solution caused a collapse of the layered structure at considerably lower molar concentration in comparison to treatment using hydrogen peroxide solution.

Kehal et al. [62] modified vermiculite from Palabora by the combination of the thermal shock $\left(700^{\circ} \mathrm{C}\right)$, chemical exfoliation $\left(80^{\circ} \mathrm{C}\right.$ in the presence of $\left.\mathrm{H}_{2} \mathrm{O}_{2}\right)$ and ultrasonic treatments ( $20 \mathrm{kHz}, \mathrm{H}_{2} \mathrm{O}$ or $\mathrm{H}_{2} \mathrm{O}_{2}$ ) to improve the adsorption of boron. Authors found that only $1 \mathrm{~h}$ treatment of vermiculite in ultrasound and $35 \mathrm{wt} . \% \mathrm{H}_{2} \mathrm{O}_{2}$ produced small particles of drastically decreased density from $1.026 \mathrm{~g} \mathrm{~cm}^{-3}$ for raw vermiculite to about $0.23 \mathrm{~g} \mathrm{~cm}^{-3}$. Furthermore, it was found by acido-basic titrations, that breaking of the particles by $20 \mathrm{kHz}$ sonication induced the generation of $\mathrm{OH}$ groups on the edges of the layers which acted as active adsorption sites.

\section{Vermiculite particles as carrier of silver nanoparticles}

The negative surface charge that results from the ion substitution or from the site vacancies at the tetrahedral and/or octahedral sheets predetermined the use of layered 2:1 phyllosilicates as substrates for the growth of metallic nanoparticles. Uncompensated charges occur at the broken edges of the clay mineral layers, predominantly at the hydroxyl groups. The cations like $\mathrm{Al}^{3+}$ or $\mathrm{Fe}^{3+}$, which typically occupy the octahedral positions, remain at the crystal edges, i.e. at the Lewis acid sites, where they coordinate water molecules. The exchangeable cations between the layers (at the Brønsted acid sites) compensate the negative charge and may be easily exchanged by other metal cations [63,64]. The reduction of the metal cations on the clay minerals matrix initiates the growth of nanoparticles preferably on 
the surface, because the interlamellar space of clay minerals limits the particle growth [6570].

The metal nanoparticles are investigated in the function of biosensors, label for cell and cancer therapeutics. The silver nanoparticles have shown to be a promising antiviral material. The strong toxicity of several silver compounds to a wide range of microorganisms is well known. Silver acts as catalyst of the oxidation of the microorganisms, which leads to the disruption of electron transfer in bacteria [71,72]. Silver offers sufficiently small repulsion to oxygen, thus only a small amount of thermal energy is required to move the atomic oxygen readily through its crystal lattice [73]. Monovalent silver ions have a high affinity to sulfhydryl (-S-H) groups in bacteria cells. The resulting stable $-\mathrm{S}-\mathrm{Ag}$ bonds inhibit the hydrogen transfer and prevent the respiration and the electron transfer. After exposing silver containing molecular oxygen to aqueous media, the molecular oxygen reacts quickly with sulfhydryl $(-\mathrm{S}-\mathrm{H})$ groups on the surface of bacteria and replaces hydrogen [74]. Silver nanoparticles exhibit cytoprotectivity towards HIV-1 infected cells [75]. The biological distribution as well as the potential toxicity of silver nanoparticles on the montmorillonite substrate was studied using Swiss mice [76]. The animal study demonstrated that the Ag-montmorillonite was nontoxic, showed no immune response, exhibited increased blood half-life and neurotransmission. Based on the study authors noted that Ag-montmorillonite enables diverse applications in life sciences such as drug development, protein detection and gene delivery for any organs, lungs and brain in particular.

The catalytic activity of silver particles depends on their size, shape and the size distribution as well as chemical-physical environment $[77,78]$.

Silver nanoparticles, size about $2 \mathrm{~nm}$, were usually prepared by chemical reduction from silver nitrate under ultraviolet irradiation [79]. Another method employed reduction with sodium borohydride [80]. During this reaction, irregular silver nanoparticles with the size between 1.5 and $2.5 \mathrm{~nm}$ nucleate first. This rapid nucleation was followed by the growth of these nuclei into aggregates of circular particles with the size of approximately 12-16 nm. Several approaches have been investigated to prepare silver nanoparticles with well-defined size and morphology. The available free-network spaces between hydrogel networks helped to grow and to stabilize the nanoparticles [81-86].

The antibacterial activity of silver-montmorillonite and copper-montmorillonite studied Magaňa et al. [87]. The authors stated that the overall antibacterial effect was related to the surface characteristics of the sample and to the quantity of silver. Similarly, the antibacterial behaviour of silver grown attached to copper-palygorskite characterized Zhao et al. [88]. Valášková et al. [89] have prepared and characterized Ag nanoparticles on vermiculite and compared them with Ag nanoparticles on montmorillonite. The antibacterial activity of both nanocomposite types was tested on two bacteria strains. The Gram negative (G-) strain was represented with two bacteria Klebsiella pneumoniae (K. pneumoniae, 9CCM 4415) and Pseudomonas aeruginosa (P. aeruginosa, CCM 1960), and the Gram positive (G+) strain using two bacteria Staphylococcus aureus (S. aureus, CCM 3953) and Enterococcus faecalis (E. faecalis, 
CCM 4224). K. pneumoniae resides in the normal flora of the mouth, skin and intestines. $P$. aeruginosa is the most common pathogen isolated from patients, who have been hospitalized longer than one week. S. aureus is a constituent of the skin flora that is frequently found in the nose and on the skin. E. faecalis inhabits the gastrointestinal tracts of humans and other mammals.
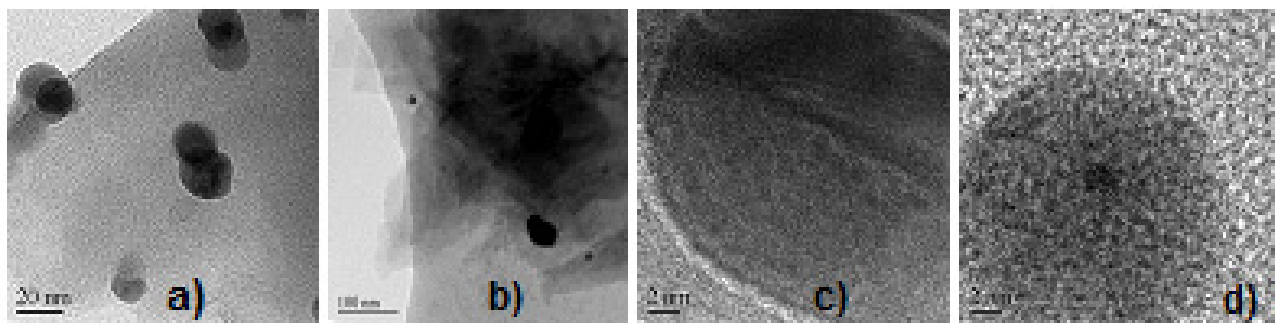

Figure 2. TEM images of silver nanoparticles on montmorillonite (a) and vermiculite substrates (b). HRTEM images of nanoparticles grew together (c) and microstructure of the Ag nanoparticles (d); (with courtesy of dr. Valter Klemm)

Nanocrystalline particles of silver reduced from the solution of silver nitrate on the clay mineral substrates were characterized using TEM and HRTEM. Transmission electron microscopy (TEM) revealed silver nanoparticles grown on the surface of both clay minerals of the mean size between 40 and $50 \mathrm{~nm}$. Small Ag particles were substantially smaller than $20 \mathrm{~nm}$. Furthermore, TEM/HRTEM found essential differences in the size distribution of the $\mathrm{Ag}$ particles grown on the surface of the montmorillonite and on the surface of the vermiculite. On montmorillonite, all Ag particles grew with a similar size and were well distributed on the surface (Fig. 2a). Huge Ag particles with the size much larger than $50 \mathrm{~nm}$ were observed only on the edges of the montmorillonite flakes. The size of the Ag particles grown on the surface of vermiculite was very heterogeneous (Fig. 2b). Some of nanoparticles were agglomerated or grew together (Fig. 2c). A lot of small particles contained smaller domains with high defect density. Microstructure of the Ag nanoparticles showed crystallites disorientation with a lot of defects, especially different planar defects (Fig. 2d).

Based on the results of the microstructure analysis of silver nanoparticles and clay mineral substrates authors $[36,70]$ assumed the manner of growth of nanoparticles on the surface of vermiculite and montmorillonite.

The particle growth process began after the previous docking of silver (precipitated from the solution of $\mathrm{AgNO}_{3}$ ) on the clay mineral surface. During their further growth, the $\mathrm{Ag}$ nanoparticles separated the clay mineral crystallites into several domains. Single nanocrystalline particles of $\mathrm{Ag}$ grow next to each other and then growing to larger nanoparticles with many microstructure defects. Still, the atomic ordering of the Ag nanoparticles at the silver/clay mineral interface is controlled by the local orientation of the clay mineral matrix. During the further growth, larger Ag nanoparticles re-crystallize by reducing the energy of their internal defects through the rearrangement and through the conservation or formation of the low-energy boundaries (as it was observed by HRTEM). 
Differences between silver nanoparticles on the vermiculite and montmorillonite substrates authors confronted with the different sources of negative layer charge. When at dioctahedral montmorillonite negative layer charge results from an octahedral substitution of magnesium for iron and the substitution of $\mathrm{Si}^{4+}$ in tetrahedra is negligible [90] the trioctahedral vermiculite has a negative charge resulting mainly from the substitution of trivalent cations for $\mathrm{Si}^{4+}$ in tetrahedra [9]. Further it was found that montmorillonite and vermiculite after treatment with the silver nitrate solution released the $\mathrm{Na}^{+}, \mathrm{K}^{+}, \mathrm{Ca}^{2+}$ and $\mathrm{Mg}^{2+}$ cations from the interlayer space of both clay minerals and from the octahedral positions in the montmorillonite. Such structural change allowed the $\mathrm{Ag}^{+}$to be incorporated in the host structure of the clay minerals through their surface and edges. The total amount of silver on vermiculite was higher than on the montmorillonite. The size distribution of the $\mathrm{Ag}$ nanoparticles was much more homogeneous on the montmorillonite substrate than on the vermiculite. The lower negative layer charge of montmorillonite results from the substitution of cations, which are located at the octahedral positions, is responsible for a uniform size of the Ag nanoparticles. The Ag particles with the size much larger than $50 \mathrm{~nm}$ were only on the edges. The negative layer charge of vermiculite as a consequence of the charge on tetrahedra can hold higher content of silver than montmorillonite.

Both sample series of silver/vermiculites and silver/montmorillonites, showed good inhibitory action against the Gram negative bacteria strains. The higher content of silver reduced on vermiculite predestines silver/vermiculite to be stronger antibacterial agent than silver/montmorillonite.

\section{Vermiculite nanofillers to polymer/clay nanocomposites}

Nanocomposites have at least one ultrafine phase dimension, typically in the range of 1-100 $\mathrm{nm}$, and exhibit other properties with comparison to the micro- and macro-composites. The clay-polymer nanocomposite could be considered as "one-nano-dimensional" because the clay filler has one dimension at the nanometer scale [91]. The high aspect ratio of layered silicate nanoparticles is ideal to modify the properties of the polymer, but the hydrophilic nature of silicate surfaces impedes their homogeneous dispersion in the organic polymer phase [92]. On the other hand it was found that polymers can interact with the external surface of clay minerals and also penetrate into the nano- structural spaces, holes and tunnels [93].

The polymer nanocomposites exhibit new and sometimes improved properties that are not displayed by the individual phases or by their conventional composite counterparts. Significant improvement of mechanical properties, thermal stability, resistance to solvent swelling and suppression of flammability have been achieved with the only up to $5 \mathrm{wt}$.\% exfoliated layered silicates nanoparticles in polymer matrix [94-97]. The development of clay-polymer nanocomposites at low clay loadings (3-7 wt \%) as advanced structural materials brings significant improvements in mechanical strength and stiffness, enhanced gas barrier behavior, reduced linear thermal expansion coefficients, and increased solvent resistance in comparison with pristine polymers. 
The hydrophilic clay minerals are commonly treated with ammonium cations with long alkyl chains to improve the compatibility between the silicate layers and the polymer matrix. The methods used for the preparation of clay-polymer nanocomposites, include solvent intercalation, in situ polymerization, and melt-compounding [98-102]. Both solvent intercalation and in situ polymerization allow polymer chains to enter into the galleries of silicate clays. Melt blending is more attractive because the nanocomposites can be processed by conventional methods such as extrusion and injection molding. The influences of the addition of various types of clays on the non-isothermal crystallization process of thermoplastics have been studied by several researchers. Fornes and Paul [103] found that depending on the dispersion of clays in thermoplastic matrices the clay nanofillers can either promote or retard the crystallization of polymers and observed that the degree of crystallinity of nanocomposites showed a strong dependence on the cooling rates.

Polyethylene (PE) is one of the most widely used polyolefins. The molecular structure is generally simply written by the formula $\left(\mathrm{CH}_{2}\right) n$, where $n$ is very large. The PE specimen may contain chains of different lengths [104]. Low-density PE (LDPE) contains many statistically placed paraffinic branches. The defects in the arrangement of chains reduce the structure crystallinity [105]. When mixing PE with hydrophilic clay minerals the additives can play a role of a polymeric surfactant, or they may act as a compatibilizer when mixed with organophilized clay minerals. The polar additives or charge of carriers introduce dipole moments in PE [106-109].

Clay mineral vermiculite (VER) was used as the clay mineral nanofiller into polymer matrix and was intercalated with the maleic anhydride into polyamide [110], polyethylene [109], and polypropylene $[89,111]$. It should be noted that nanocomposites of polypropylene with nanofiller of VER were prepared without any compatibilizer by solid-state shear compounding (S3C) using pan-mill equipment [112]. Vermiculite particles were only partly intercalated with polypropylene and exfoliated in PP matrix (Shao et al., 2006).

Organovermiculite nanofiller octadecylamine/vermiculite (ODA/VER) was exfoliated in polypropylene (PP) [89]. The organovermiculite nanofillers were prepared in three ways. Sample 1 was original VER (Fig. 3a) intercalated using melt intercalation with octadecylamine (ODA). Sample 2 was VER milled in jet mill and intercalated with ODA (Fig. 3b). Sample 3 was VER exfoliated using an oxidizing agent potassium persulfate [61] and subsequently intercalated with ODA.

The thermal compounding of the organovermiculites (4 wt. \%) with maleated PP caused the partial deintercalation of organovermiculites. As the jet milled original VER flakes have corrugated edges [113] in PP remained intercalated only in their central parts. The frayed edges and small particles showed somewhat higher interlayer distances and the penetration of polymeric segments from the softened polymer matrix was possible. The sample 2 was very well dispersed within PP matrix. The layered vermiculite structure after exfoliation with potassium persulfate was destroyed [61] and therefore intercalation of ODA molecules into the interlayer was limited (sample 3). On the X-ray diffraction patterns of composite sample 2 in PP authors identified new reflection of the orthorhombic $\gamma$-PP in addition to the 
$\alpha$-PP. According to the literature it is known that the formation of $\gamma$-PP in $\alpha$-PP takes place when the VER particles reduce the PP chain mobility within the narrow space surrounded by the dispersed clay mineral particles [114].
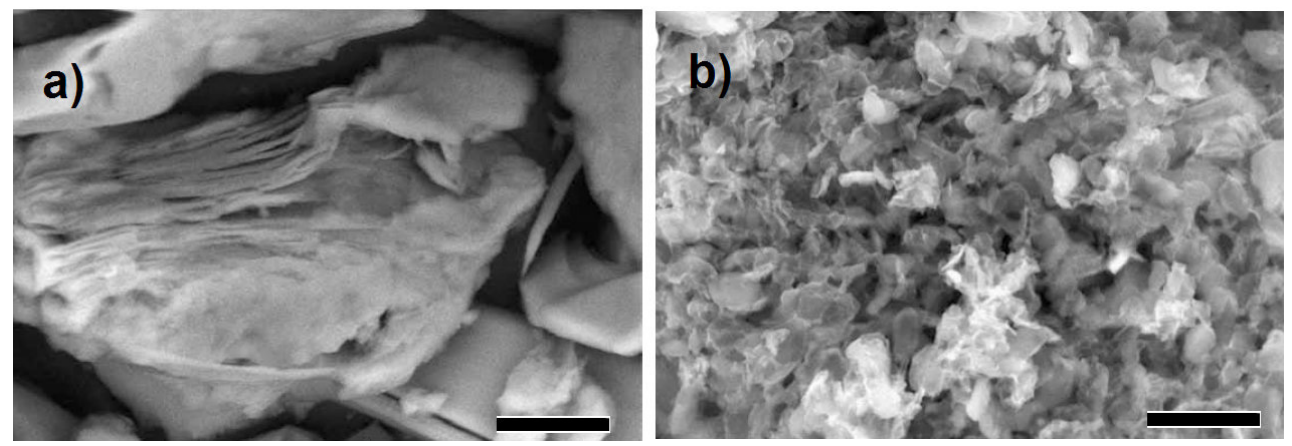

Figure 3. SEM images of original particle VER (a) and jet milled VER intercalated with ODA (sample 2). Bar shows $10 \mu \mathrm{m}$.

Thermal stability of PP and PP/VER nanocomposites was evaluated by thermogravimetric analysis (Fig. 4).
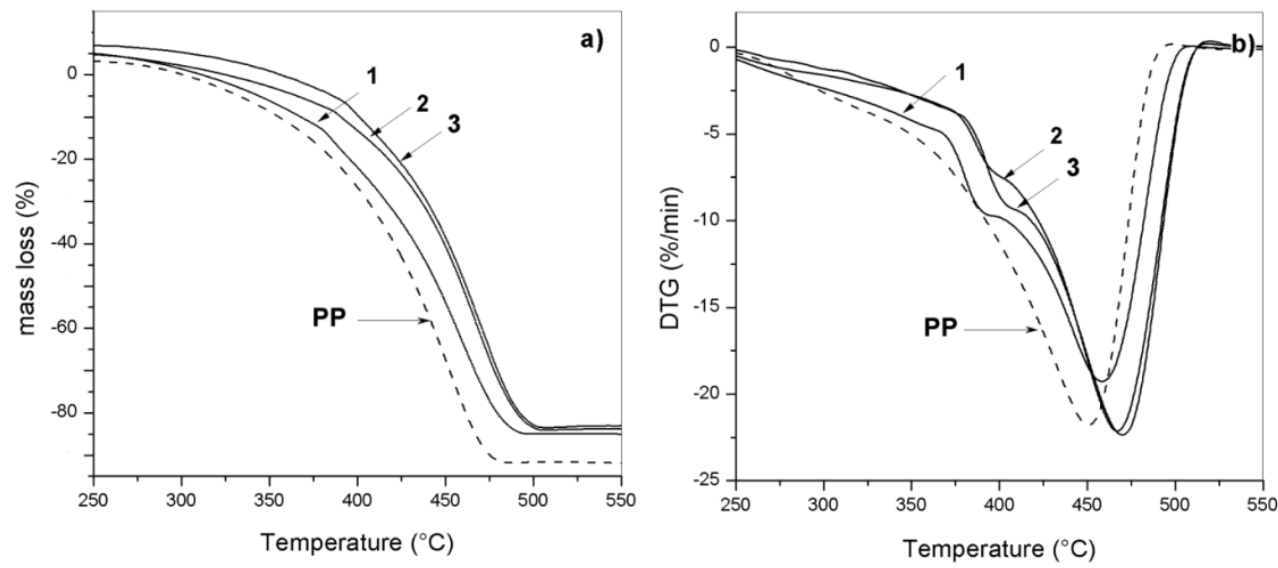

Figure 4. TG and DTA of ODA/VER nanofillers in PP.

The thermal resistance of the nanocomposites was evaluated by comparing temperatures at the certain weight loss points. Decomposition of pure PP started at $247^{\circ} \mathrm{C}$. The degradation point characterized by onset temperature followed the sequence: sample $3\left(286^{\circ} \mathrm{C}\right) \rightarrow$ sample $2\left(273^{\circ} \mathrm{C}\right) \rightarrow$ sample $1\left(267^{\circ} \mathrm{C}\right)$.

At $5 \%$ mass loss, the dispersed exfoliated organovermiculite nanofillers sample 2 showed about $51^{\circ} \mathrm{C}$, and sample 3 (weekly exfoliated in PP) even about $65^{\circ} \mathrm{C}$ higher thermal resistance than pure $\mathrm{PP}$. 
This agrees with observations of Gilman [112], who reported that intercalated clay mineral particles in polymer matrix make composite a much more resistant to temperatures than exfoliated particles.

Nanoclays are clay minerals optimized for use in clay nanocomposites- multi-functional material systems with several property enhancements targeted for a particular application. The polymer-clay nanocomposites have been reviewed in several literature sources [112118].

Depending on the structure of dispersed clay-filler in the polymeric matrix, the composites can be classified as intercalated or exfoliated nanocomposites. Polymer nanocomposites can be prepared by two main processes, that is, in situ polymerization and melt compounding.

Use of nano-sized filler particles to form polymer composites has attracted much attention in recent years because of the potential performance advantages that could create new technological opportunities. Potential benefits include increased mechanical strength, decreased gas permeability, superior flame-resistance, and even enhanced transparency when dispersed nanoclay plates suppress polymer crystallization [119-123].

The key issue is to obtain an effective dispersion and exfoliation of the platelets into the polymer matrix to yield well-aligned, high-aspect ratio particles for mechanical reinforcement or a tortuous diffusion pathway for improved barrier properties [124]. In situ polymerization process consists of intercalation of monomer as precursor species, followed by their polymerization inside the interlayer of clay mineral. Numerous nanocomposite materials were prepared by method with clay having inorganic metallic interlayer cation, which can promote formation of monomer radical inducing its polymerization, or modifying agent for nonpolar polymers. Both thermosets and thermoplastics have been incorporated into nanocomposites.

Simulation techniques become an integral part of experimental techniques, since the information about the spatial arrangement of molecules within the interlayer is hard to obtain without the aid of computer simulation. It offers a range of modeling and simulation methods, covering the length range from the subatomic quantum scale, through the molecular level, to the micrometer scale. Methods to model the behavior of systems on each of these scales are combined with analytical instrument simulation and statistical correlation techniques, allowing detailed study of structure, properties, and processes. Molecular modeling using empirical force field represents a way to preliminary estimation of the hostguest complementarity and prediction of structure and properties for nanomaterial design in molecular nanotechnology.

\section{Industrial vermiculite nanocomposites}

The group of vermiculite-polymeric nanocomposites, where vermiculite or its silicate layers in the final composite stage is altering properties of full system, represents economically and technologically unpretentious materials. Vermiculite here enters the composite system unmodified; it means that it keeps its original characteristics. Usually, polymer and/or 
layered silicate nanocomposites are synthesized from polymeric macromolecules directly or from monomers followed by in situ polymerization to intercalate into and then enlarge the interlayer of the used clay.

The struggle to prepare nanocomposites is affected by many factors such as the blending or reaction time, temperature and the affinity between the host and the matrix. Moreover, the intercalated nanocomposites instead of the exfoliated nanocomposites are commonly gained in most cases. Generally, dispersion as well as delamination of vermiculite in polymer matrices is observed using electron microscopy and XRD techniques.

Three main approaches have been used in the preparation of clay-polymer composites: (1) melt blending, (2) solution blending, and (3) in situ polymerization. However, homogeneity at nanoscale level may not be fully achieved using these methods. One way of approaching this problem is complete delamination of the clay particles to give colloidal dispersions of single layers in a suitable solvent and restacking the layers in presence of guest species.

Utilization of vermiculite in nanocomposite is not as extensive as for montmorillonite. Most of the applications limits low swell ability of vermiculite compare to montmorillonite. However, several main streams of applications were introduced.

Superabsorbents are a type of loosely crosslinked hydrophilic polymer that can swell, absorb, and retain a large volume of aqueous or other biological fluid. The superabsorbents have found extensive applications in many fields such as agriculture, hygienic products, wastewater treatment, drug-delivery systems, etc.

The conventional superabsorbents are based on expensive fully petroleum-based polymers. Their production consumes lots of petroleum and their usage can also cause a nonnegligible environment problem. New types of superabsorbents by introducing naturally available raw materials as additives were desired. The incorporation of clays reduces production cost, and also improves the properties (such as swelling ability, gel strength, mechanical, and thermal stability) of superabsorbents and accelerates the generation of new materials for special applications. The properties of traditional superabsorbent could be enhanced by incorporating vermiculite [125]. It is expected that organomodification of vermiculite can further improve dispersion and performance of the resultant nanocomposite. The superabsorbent nanocomposites were prepared from natural guar gum and organovermiculite by solution polymerization and analyses indicated that organovermiculite was exfoliated during polymerization and uniformly dispersed in the polymeric matrix [126].

In the superabsorbent field recently, much attention has been paid especially to layered silicate as favorable compound of absorbent composites. Polyacrylate (PAA)-vermiculite superabsorbent composites were tested for their absorption abilities. Acrylamide and acrylic acid mixed with vermiculite were polymerized. Final nanopowders had the particle size in range 40-80 mesh. Nanocomposite was immersed in examined medium and let to reach swelling equilibrium for $4 \mathrm{~h}$, which resulted in absorption of water into network of composite and the formation of hydrogel. Swelling behavior of the superabsorbent composites of various cations from salt solutions $\left(\mathrm{NaCl}, \mathrm{CaCl}_{2}\right.$, and $\left.\mathrm{FeCl}_{3}\right)$, anions salt 
solutions $\left(\mathrm{NaCl}, \mathrm{Na}_{2} \mathrm{SO}_{4}\right.$, and $\left.\mathrm{Na}_{3} \mathrm{PO}_{4}\right)$, and $\mathrm{pH}$ solutions were observed. Equilibrium water absorbency for the PAA-vermiculite superabsorbent composite was significantly affected by the content of vermiculite. The highest water absorbency was obtained when $20 \mathrm{wt} . \%$ of vermiculite was incorporated. Water absorbency of these composite materials was also significantly dependent on properties of external saline solutions, including valence of ions, ionic strength, and $\mathrm{pH}$ values. FTIR indicated that the reactions occur between - $\mathrm{COO}^{-}$ groups and $-\mathrm{OH}$ groups on the surface of vermiculite. SEM and TEM studies illustrated more finely dispersion of the clay particle in the polymer matrix. In addition, XRD analysis showed that the polymerization reaction is performed on the surface of vermiculite and the $d$-space is not changed. TGA indicated that introduction of vermiculite into the polymer network leads to an increase in thermal stability of the composites. The reaction between organics and clay is related to the structure and properties of clay. The equilibrium water absorbency decreases with increasing clay content owing to the increasing crosslinking points and the decreasing percentage of hydrophilic groups in polymeric network. The vermiculite based nanocomposite acquired high- water absorbency in $\mathrm{CaCl}_{2}$ aqueous solution [133].

Simple mixing technique of vermiculite into polymer matrix could be applied in case of preparation of membranes. Several minerals, including vermiculite 10-100 $\mu \mathrm{m}$ particle size, were tested for having desirable features to be used in membrane. Many membranes are designed to be selectively permeable, commonly intended for use in membrane separations or to be impermeable barriers to protect a surface or a product. Paint, food wrap, and electronic packaging are examples. For these barrier membranes, we seek polymers through which solutes such as water, oxygen, and chloride permeate slowly, rather than rapidly. Developing barrier membranes containing aligned mineral flakes could be solution for those requirements. Since mineral flakes are generally crystalline, they have very low permeability, and can reduce the permeability of the composite film. The permeability of polymer films can be reduced dramatically with many layers of thin mineral flakes aligned parallel to the film's surface.

As the gas barrier membrane could be utilized of butyl rubber-vermiculite nanocomposite coating in form of thing layer. The coating formulation consisting of a butyl rubber (polyisobutylene $\left.\left(\mathrm{C}_{4} \mathrm{H}_{8}\right)_{n}\right)$ latex, which is well known among elastomers for its superior gas barrier characteristics, to which dispersion of exfoliated vermiculite was added. The gas permeability and diffusion coefficients of the nanocoating compare to pure polymer were altered remarkably by the presence of the high loadings of vermiculite. The gas permeability was reduced by 20-30-fold by the vermiculite. Diffusion coefficients computed from time lag data were reduced by two orders of magnitude. Solubility coefficient obtained from the time lag observation increased significantly with vermiculite content in contradiction to that expected by theory (the solubility coefficient should decrease with filler loading since the volume of available polymer is decreased). The excess sorption appears to be the effect of gas adsorption by the vermiculite [127].

Mixing dilution of polyvinyl alcohol (PVA) $\left(\mathrm{C}_{2} \mathrm{H}_{4} \mathrm{O}\right)_{n}$ with vermiculite suspension both in water was prepared membrane - precursor, which was later cast on block heated to $75^{\circ} \mathrm{C}$. For a 
film with a volume fraction $\phi$ of flakes of aspect ratio $\alpha$, the permeability reduction is expected to be proportional to $\alpha \phi$ for the dilute limit $(\phi<<1$ and $\alpha \phi<1)$ but proportional to $(\alpha \phi)^{2}$ in the semidilute limit $(\phi \ll 1$ but $\alpha \phi>1)$. Permeability of hydrochloric acid and sodium hydroxide across films containing mica or vermiculite in PVA agree with the second, semidilute prediction. These improvements in barrier properties are independent on the flake size, permeate, and polymer chemistry [128].

However, it is very difficult to prepare an entirely exfoliated nanocomposite using natural vermiculite as nanofiller by conventional techniques. Therefore, vermiculite has been successfully delaminated with acid treatment and used to mix with engineering polymer directly to synthesize polymer-vermiculite nanocomposites [129, 130]. Acid delaminated vermiculite was successfully utilized for preparation of PVA nanocomposite. The properties of composite significantly depend on the preparation procedure for the reason that chemical reactions and physical interactions involved. Two steps preparation, delamination with hydrochloric acid and then addition to the PVA solution using various mixing times. The positive effect of the vermiculite content on the thermal behavior of the PVA-vermiculite blends was observed [131].

The utility of the PVP-vermiculite nanocomposite materials can be found in area of wastewater cleaning as the remover of color from dye wastewater, since vermiculite is an excellent adsorbent for basic blue dye, requiring moderately short contact times. The phenols and iodine form a molecular complex with pyridine, as well as with PVP. Thus, common impurities from the industrial waste stream such as iodine, weak acids, and phenol can be removed using the PVP-vermiculite nanocomposite. It can also be used as a reusable mild acid scavenger, which can be easily removed from the reaction medium by filtration. The cost of vermiculite is $10 \%$ of activated carbon and it is possible to regenerate it by simple heating, so it offers an attractive alternative for waste removal and recovery.

Nanocomposites poly(4-vinylpyridine(VP)) (PVP) and poly(N-vinyl-2-pyrrolidinone(NVP)) (PNVP) both combined with vermiculite have been synthesized by the intercalative redox polymerization of monomer in the gallery of $\mathrm{Cu}^{2+}$ ion-exchanged vermiculite $\left(\mathrm{Cu}^{2+}\right.$ serves as polymerization agent). The formation of a single filament of the PVP polymer in the vermiculite gallery is confirmed by the increase in gallery spacing of $0.47 \mathrm{~nm}$ as indicated by XRD analysis. XRD analysis following intercalative polymerization of PNVP indicates the presence of two prominent peaks with the corresponding basal spacing d002 $=1.43 \mathrm{~nm}$ (intercalated) and $0.99 \mathrm{~nm}$ (not intercalated), suggesting the formation of a partially intercalated hybrid material. The amount of polymers present in the gallery is found to be around $20 \mathrm{wt} . \%$ by TG analysis. Presence of the polymer in vermiculite gallery results in enhanced thermal stability that is evident from the increase of initial decomposition temperature by $300^{\circ} \mathrm{C}$. Differential scanning calorimetry of the nanocomposite indicates that the polymer is confined to a restricted geometry because of the absence of a glass-transition temperature, which confirms the XRD finding. The IR absorption peaks corresponding to PVP and the expected PVP of UV $\pi-\pi^{*}$ transition at $275 \mathrm{~nm}$, along with the XRD, and thermal data confirms that the gallery expansion is owing to the PVP filament [132]. 
The nanocomposites consisting of the emeraldine salt of polyaniline (PANI) and layered vermiculite were synthesized to improve thermal stability of nanocomposite [134]. Emeraldine salt (base) is regarded as the most useful form of PANI owing to its high stability at room temperature. PANI-vermiculite nanocomposites were prepared via in situ polymerization of monomer compounded with vermiculite. Vermiculite silicate layers could be highly dispersed within PANI bulk thanks to pretreatment of vermiculite with hydrochloric acid. The introduction of nanolayers of vermiculite improves greatly the thermal stability of nanocomposite, but its electrical conductivity decrease slightly only, as demonstrated by TGA and electrical conductivity measurements.

An increased understanding, on the micro- and nanolevel, of polymers at surfaces and in confined geometries assists in the development and improvement of new technologies. Of special interest is to understand the nature of the glass transition - not fully solved problem of condensed matter physics. By confining molecules in very small spaces (e.g., clay gallery), the existence or not of a length scale associated with molecular motions responsible for the glass transition can be established. The increment of its relaxation strength in the clay has been related to the $2 \mathrm{D}$ geometry of the confinement. These polymers have a dipole moment component parallel to the chain and, therefore, the total dipole vector is proportional to the end-to-end vector and so the overall chain dynamics can be measured by dielectric spectroscopy.

Vermiculite was selected for study the molecular dynamics of oligomeric poly(propylene glycol (PG)) (PPG) liquids $\left(\mathrm{M}_{\mathrm{w}}=1200,2000\right.$, and $\left.4000 \mathrm{~g} \mathrm{~mol}^{-1}\right)$. The thickness of the liquid layers was $0.55 \mathrm{~nm}$ in the case of PG and $0.37 \mathrm{~nm}$ for 7-PG and PPG. The PG oligomers form a flat monolayer in vermiculite gallery with their methyl groups pointing in the direction of the clay surfaces. In contrast, the monomers are probable orientated either perpendicular to the clay layers or parallel to the layers, but with the methyl groups pointing toward a clay surface. The dynamics generally become slower with increasing chain length but the dynamics of the 7-mers was established to be faster than for the single monomers. A possible explanation for the fact may be that the $\mathrm{OH}$ end groups of the monomers are linked together forming a network, and, as a result, slow down the diffusion at temperatures low enough to keep the network structure intact [135]. The PPG confined in Na-vermiculite has been studied by broadband dielectric spectroscopy. In addition to the temperature dependence of the main $(\alpha-)$ relaxation process and the related high-temperature translational or segmental diffusion, the normal mode relaxation process was studied for all samples in both bulk and confinement. For the normal mode process the relaxation rate and the temperature dependence of the relaxation time in the clay is drastically shifted to lower frequencies compared to that of the bulk material. The $\alpha$-process relaxation time is only slightly affected by the confinement.

The fact that interactions of PPG with the clay surfaces are very weak was implied based on similar temperature dependence of the relaxation time the $\alpha$-relaxation in both bulk and confinement [136]. Relaxation process corresponds to the molecular motions of translational character and that it is almost unaffected by the present true $2 \mathrm{D}$ confinement, in contrast to the dielectrically active normal mode of PPG which is substantially slower in the 
confinement. Thus, there is no indication, for none of the confined liquids, that the $\mathrm{OH}$-end groups should form strong hydrogen bonds to the clay surfaces. In fact, the rather small effect of the present confinement on the diffusive dynamics and the main relaxation time suggest that the surface interactions are considerably weaker than in many other model systems [135].

Nanocomposites based on magnetic nanoparticles supported within thermally-expanded vermiculite are extremely interesting for many applications, including its use in removing oil from water after oil spills. Two distinct magnetic nanocomposites based on thermally-expanded vermiculite pellets were treated with two different magnetic fluid samples. One of them was an ionic magnetic fluid (IMF), and the second a surfacted magnetic fluid (SMF) was consisting of oleic acid-coated nanoparticles suspended in organic medium. Magnetic fluids (MFs) are highly stable colloids consisting of nanosized magnetic particles (mainly iron oxides) suspended in a hydrophilic or hydrophobic liquid carrier. Besides numerous industrial and biomedical applications MFs can be successfully used to introduce nanosized magnetic particles into a variety of hosting structures and templates [137].

Recently, layered silicates have been used to modify bitumen. It has been found that physical properties, rheological behaviors and aging resistance of bitumen and polymer modified bitumen could be obviously improved due to barrier properties of MMT. Expanded vermiculite (EVMT) clays modified bitumen was prepared by using EVMT, cetyltrimethyl ammonium bromide (CTAB)-EVMT and octadecyl dimethyl benzyl ammonium chloride (ODBA)-EVMT as modifiers. The morphology characteristic of the modified bitumen was investigated by X-ray diffraction (XRD). The binders were aged by pressure aging vessel (PAV), in situ thermal aging and ultraviolet (UV) radiation. The phase-separated structure was observed in EVMT modified bitumen, while CTAB-EVMT and ODBA-EVMT modified bitumen formed the intercalated and exfoliated nanostructures, respectively [138].

In situ ring-opening polymerization of the cyclic oligomers in the gallery of vermiculite can form high performance polymer nanocomposites, in the absence of any catalyst and without any volatile by-products formed. The new approach allows to intercalate the silicate layers with cyclic(arylene disulfide) oligomers via direct melt compounding, and in turn to prepare in situ the corresponding nanocomposites. The cyclic arylene disulfide oligomer acts both as a precursor of polymeric matrix and as a swelling agent of the vermiculite layers. High molecular weight polymer can be formed in a few minutes [139].

A conducting polymer/inorganic host hybrid nanocomposite was created from the conductive polypyrrole (PPy) self-assembled monolayer (SAM) coated on expanded vermiculite (VMT) [140]. The conducting polymer/inorganic host hybrid composites provide the new synergistic properties, which cannot attain from individual materials. Their conductivity is more easily controlled, and the mechanical or thermal stability is improved through the synthesis of the composites. resulting in PPy/VMT nanocomposites after VMT particles surface modification.

X-ray diffraction (XRD) analysis confirmed that the main peaks of PPy/VMT nanocomposites are similar to the SAM-VMT particles, which reveal that the crystal structure of SAM-VMT is 
well maintained after the coating process under polymerization conditions and exhibit semicrystalline behavior. Thermogravimetric analysis showed that the thermal stability of $\mathrm{PPy} / \mathrm{VMT}$ nanocomposites was enhanced and these can be attributed to the retardation effect of amine-functionalized VMT as barriers for the degradation of PPy. The morphology of PPy/VMT nanocomposites showed the layered structure and encapsulated morphology. The composites possess high electrical conductivity at room temperature, weakly temperature dependence of the conductivity.

Intercalated nanocomposites comprised of poly(propylene carbonate) (PPC) and organovermiculite (OVMT) was first prepared via direct melt compounding of the alkali-vermiculite intercalated host with PPC in a twin rotary mixer. The dispersion and morphologies of OVMT within PPC were investigated by X-ray diffraction and transmission electron microscopic techniques. The results revealed the formation of intercalated-exfoliated vermiculite sheets in the PPC matrix. Because of the thermally sensitive nature of PPC, thermal degradation occurred during the melt compounding. The degradation led to a deterioration of the mechanical properties of the nanocomposites. Tensile test showed that the yield strength and modulus of the nanocomposites decrease with increasing vermiculite content [141].

\section{Polymeric bio-related nanocomposites}

Polymeric bio-related nanocomposites can be classified into two classes: (1) natural-based materials, including polysaccharides (starch, alginate, chitin/chitosan, hyaluronic acid derivatives) or proteins (soy, collagen, fibrin gels, silk); (2) synthetic polymers, such as poly(lactic acid) (PLA), poly(glycolic acid) (PGA), poly(3-caprolactone) (PCL), poly(hydroxyl butyrate) (PHB) [142].

\begin{tabular}{l|l|l}
\hline Polymer & Type & Utilization \\
\hline Poly(lactic acid) (PLA) & aliphatic polyester & $\begin{array}{l}\text { Fracture fixation, } \\
\text { interference screws, } \\
\text { suture anchors, } \\
\text { meniscus repair }\end{array}$ \\
\hline poly(glycolic acid) (PLG) & aliphatic polyester & $\begin{array}{l}\text { non-woven fibrous } \\
\text { fabrics;suture anchors, } \\
\text { meniscus repair, medical } \\
\text { devices, drug delivery }\end{array}$ \\
\hline poly(E-caprolactone) (PCL) & aliphatic polyester & $\begin{array}{l}\text { Suture coating, dental } \\
\text { orthopaedic implants, } \\
\text { bone tissue implantant }\end{array}$ \\
\hline poly(hydroxylbutyrate) (PHB) & Polyester & $\begin{array}{l}\text { material for waste } \\
\text { management strategies; } \\
\text { biocompatibility in the } \\
\text { medical devices }\end{array}$ \\
\hline
\end{tabular}

Table 1. Biopolymers for composites 
Many advantages and disadvantages characterize these two different classes of biomaterials. Synthetic polymers have relatively good mechanical strength and their shape and degradation rate can be easily modified, but their surfaces are hydrophobic and lack of cellrecognition signals. Naturally derived polymers have the potential advantage of biological recognition that may positively support cell adhesion and function, but they have poor mechanical properties. Many of them are also limited in supply and can therefore be costly [142].

During the last decade, significant attention has been focused on biodegradable polymers. Among all these polymers, poly(lactic acid) (PLA) is one of the most promising because it is thermoplastic, biocompatible and has a high strength, a high modulus, and good processability [143]. PLA also has been revealed an inefficient crystallization process for both the lower crystallization rate and crystallinity as compared with other polymers [144147].

To maximize therapeutic activity while minimizing negative side effects is the main driven force for the continuous development of new controlled drug delivery systems. Because the release of drugs in drug-intercalated layered materials is potentially controllable (Fig.5), these new materials have a great potential as a delivery host in the pharmaceutical field. Calcium clay has been used extensively in the treatment of pain, open wounds, colitis, diarrhea, hemorrhoids, stomach ulcers, intestinal problems, acne, anemia, and a variety of other health issues.

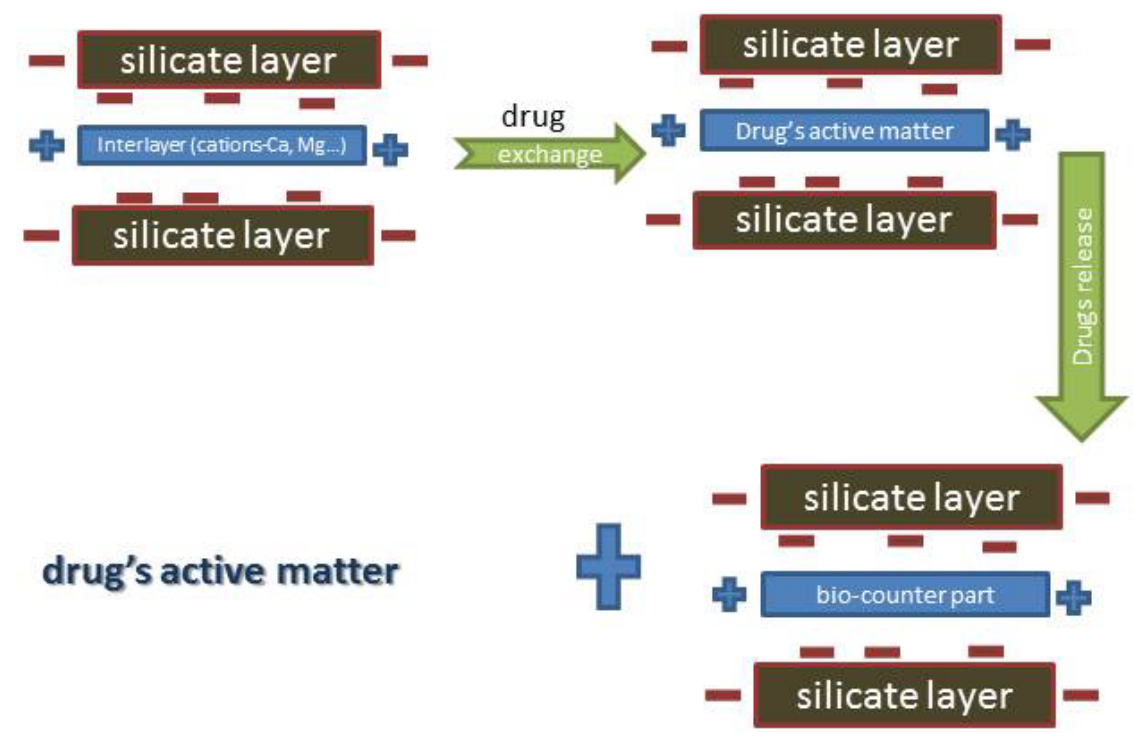

Figure 5. Schema of drugs delivery.

Bionanocomposites belong to group of materials, being the result of the combination of biopolymers and inorganic solids at the nanometer scale. These hybrid organic-inorganic 
materials are extraordinarily versatile as they could be formed from a large variety of biopolymers and also from different inorganic solid particles such as layered silicates, hydroxyapatite, cellulose and other metal oxides [148]. Among them, chitosan/layered silicate nanocomposites have received much more attention. These nanocomposites are of interest for advanced biomedical materials, as for instance tissue engineering, artificial bones or gene therapy. Other possible fields of applications are related to their mechanical, thermal and barrier properties, making this class of materials attractive for potential uses in controlled drug and pesticides delivery, membranes for food processing, drinking water purification, oxygen barrier films and food package.

Chitosan is the deacetylated product of chitin, a natural polymer found in the cell wall of fungi and microorganisms. The active groups in the chitosan structure are the free amine groups, located in the $\mathrm{C} 2$ position of the glucose residue in the polysaccharide chain, and the hydroxyl groups [148]. The chitosan/vermiculite nanocomposites have been successfully prepared with different modified vermiculite, which was treated by acid, sodium and CTAB cations. The modification and the nano-scale dispersion of the modified vermiculites were confirmed.

\section{Author details}

Marta Valášková1,2, * and Gražyna Simha Martynková1,2

${ }^{1}$ Nanotechnology Centre, VŠB - Technical University of Ostrava, Ostrava-Poruba, Czech Republic

${ }^{2}$ IT4Innovations Centre of Excellence, VŠB-Technical University of Ostrava, Ostrava-Poruba, Czech Republic

\section{Acknowledgement}

Financial support of the Czech Grant Agency (projects GA ČR 210/11/2215) and the IT4Innovations Centre of Excellence (project reg. no. cz.1.05/1.1.00/02.0070) are gratefully acknowledged.

\section{References}

[1] Guggenheim S, Martin RT (1995) Definition of Clay and Clay Mineral. Joint Report of the AIPEA Nomenclature and CMS Nomenclature Committees. Clays clay miner. 43: 255-256.

[2] Brindley GW, Bailey SW, Faust GT, Forman SA, Rich CI (1968) Report of the Nomenclature Committee (1966-67) of The Clay Minerals Society. Clays clay miner. 16: 322-324.

[3] Brindley GW, Pedro G (1972) Report of the AIPEA Nomenclature Committee. AIPEA Newsletter 7: 8-13.

\footnotetext{
${ }^{*}$ Corresponding Author
} 
[4] Guggenheim S, Adams JM, Bain DC, Bergaya F, Bigatti MF, Drits VA, Formoso MLL, Galán E, Kogue T, Stanjek H (2006) Summary of Recommendations of Nomenclature Committees Relevant to Clay Mineralogy: Report of the Association Internationale pour L'Étude des Argiles (AIPEA) Nomenclature Committee for 2006. Clays clay miner. 54: 761-772; Clay miner. 41: 863-877.

[5] Martin RT, Bailey SW, Eberl DD, Fanning DS, Guggenheim S, Kodama H, Pevear DR, Srodon J, Wicks FJ (1991) Report of the Clay Minerals Society Nomenclature Committee: Revised Classification of Clay Materials. Clays clay miner. 39: 333-335.

[6] Norrish K (1973) Factors in the Weathering of Mica to Vermiculite. Proc. int. clay. conf. 1972. Madrid, 417-432.

[7] Brindley GW, Pedro G (1976) Meeting of the Nomenclature Committee of AIPEA, Mexico City, July 21, 1975, AIPEA Newsletter 12: 5-6.

[8] Guggenheim S, Alietti A, Drits VA, Formoso MLL, Galán E, Köster HM, Paquet H, Watanabe T, Bain DC, Hudnall WH (1997) Report of the Association Internationale pour L'Étude des Argiles (AIPEA) Nomenclature Committee for 1996 Clays clay miner. 45: 298-300; Clays clay miner. 32: 493-496.

[9] Shirozu H, Bailey SW (1966) Crystal Structure of a Two-Layer Mg-vermiculite. Am. miner. 51: 1124-1143.

[10] Lagaly G (1982) Layer Charge Heterogeneity in Vermiculites. Clays clay miner. 30: 215222.

[11] Bailey SW (1980) Structures of Layer Silicates. In: Brindley GW, Brown G, editors. Crystal Structures of Clay Minerals and their X-ray Identification. Monograph 5, Mineralogical Society, London: pp. 1-124.

[12] Bailey SW, Brindley GW, Fanning DS, Kodama H, Martin RT (1984) Report of the Clay Minerals Society Nomenclature Committee for 1982 and 1983. Clays clay miner. 32: 239.

[13] Bergaya F, Vayer M. (1997) CEC of Clays: Measurement by Adsorption of a Copper Ethylene-Diamine Complex. Appl. clay sci. 12: 275-280.

[14] Rausell-Colom JA, Fernández M, Serratosa JMJ, Alcover F, Gatineau L (1980) Organisation de L'espace Interlamellaire dans les Vermiculites Monocouches et Anhydres. Clay miner. 15: 37-58.

[15] de la Calle C, Suquet H, Pons CH (1988) Stacking Order in 14.30 Å Mg-vermiculite. Clays clay miner. 36: 481-490.

[16] Jasmund K, Lagaly G, editors (1993) Tonminerale und Tone, Struktur, Eigenschaften, Anwendung und Einsatz in Industrie und Umwelt. Steinkopff Verlag, Darmstadt. 490p.

[17] Tournassat C, Greneche JM, Tisserant D, Charlet L (2003a). The Titration of Clay Minerals. I. Discontinuous Backtitration Technique Combined with CEC Measurements. J. colloid interface sci. 273: 224-233.

[18] Tournassat C, Ferrage E, Poinsignon C, Charlet L (2003b). The Titration of Clay Minerals. II. Structure-Based Model and Implications for Clay Reactivity. J. colloid interface sci. 273: 234-246.

[19] Mathieson AM, Walker GF (1954) Crystal Structure of Magnesium-Vermiculite. Am. miner. 39: 231-255. 
[20] Vali H, Hesse R (1992) Identification of Vermiculite by Transmission Electron Microscopy and X-ray Diffraction. Clay miner. 27: 185-192.

[21] Collins DR, Fitch AN, Catlow RA (1992) Dehydration of Vermiculites and Montmorillonites: a Time-Resolved Powder Neutron Diffraction Study. J. mat. chem. 8: 865-873.

[22] Reichenbach HG, Beyer J (1994) Dehydration and Rehydration of Vermiculites: IV. Arrangement of Interlayer Components in the $1.43 \mathrm{~nm}$ and $1.38 \mathrm{~nm}$ Hydrates of Mgvermiculite. Clay miner. 29: 327-340.

[23] Reichenbach HG, Beyer J (1995) Dehydration and Rehydration of Vermiculites: II. Phlogopitic Ca-vermiculite. Clay miner. 30: 273-286.

[24] Ruiz-Conde A, Ruiz-Amil A, Pérez-Rodríguez JL, Sánchez-Soto PJ (1996) DehydrationRehydration in Magnesium Vermiculite: Conversion from Two-One and One-Two Water Hydration States through the Formation of Interstratified Phases. J. mat. chem. 6: 1557-1566.

[25] Marcos C, Argüelles A, Ruíz-Conde A, Sánchez-Soto PJ, Blanco JA (2003) Study of the Dehydration Process of Vermiculites by Applying a Vacuum Pressure: Formation of Interstratified Phases. Mineral. mag. 67: 1253-1268.

[26] Marcos C, Arango YC, Rodriguez I (2009) X-ray Diffraction Studies of the Thermal Behaviour of Commercial Vermiculites. Appl. clay sci. 42: 368-378.

[27] de la Calle C, Suquet H (1988). Vermiculite. In: Bailey SW, editor. Reviews in Mineralogy, Vol. 19, Hydrous Phyllosilicates. Mineralogical Society of America, Washington: pp. 455-496.

[28] Weiss Z, Valvoda V, Chmielová M (1994) Dehydration and Rehydration of Natural Mgvermiculite. Geol. carpath. 45: 33-39.

[29] Walker GF (1956) Mechanism of Dehydration of Mg-vermiculite. Clays clay miner. 4: 101-115.

[30] de la Calle C, Dubernat J, Suquet H, Pezerat H, Gaulthier J, Mamy J (1975) Crystal Structure of Two-Layer Mg-vermiculites and Na-, Ca-vermiculites. In: Bailey SW, editor. Proc. Internat. Clay Conf. Mexico City: Applied Publishing, Wilmette, Illinois: pp. 201-209.

[31] de la Calle C, Suquet H, Pezerat H (1975) Glissement de Feuillets Accompagnant Certains Echanges Cationiques dans les Vermiculites. Bull. du groupe français des argiles 27: 31-49.

[32] de la Calle C, Suquet H, Dubernat J, Pezerat H (1978) Mode d'Empilement des Feuillets dans les Vermiculites Hydratees a 'deux Couches.' Clay miner. 13: 275-297.

[33] de la Calle C, Suquet H, Pezerat H (1985) Vermiculites Hydratees a Une Couche. Clay miner. 20: 221-230.

[34] Temuujin J, Okada K, Mackenzie KJD (2003) Preparation of Porous Silica from Vermiculite by Selective Leaching. Appl. clay sci. 22: 187-195.

[35] Wiewóra A, Pérez-Rodríguez JL, Pérez-Maqueda LA, Drapala J (2003) Particle Size Distribution in Sonicated High- and Low-Charge Vermiculites. Appl. clay sci. 24: 51-58.

[36] Valášková M, Hundáková $M$, Kutláková Mamulová $K$, Seidlerová J, Čapková P, Pazdziora E, Matějová K, Heřmánek M, Klemm V, Rafaja D (2010) Preparation and 
Characterization of Antibacterial Silver/Vermiculites and Silver/Montmorillonites. Geochim. cosmochim. ac. 74: 6287-6300.

[37] del Rey-Perez-Caballero FJ, Poncelet G (2000) Microporous $18 \AA$ Al-pillared Vermiculites: Preparation and Characterization. Micropor. mesopor. mat. 37: 313-327.

[38] da Fonseca MG, Wanderley AF, Sousa K, Arakaki LNH, Espinola JGP (2006) Interaction of Aliphatic Diamines with Vermiculite in Aqueous Solution. Appl. clay sci. 32: 94-98.

[39] Bergaya F, Jaber M, Lambert JF (2011) Clays and Clay Minerals. In: Galimberti M, editor. Rubber Clay Nanocomposites: Science, Technology and Applications, Wiley: pp 3-44.

[40] Guggenheim S (Chair), Bergaya F, Brigatti MF, Galán E, Drits V, Formoso MLL, Kogure T, Stanjek H, ex officio: Adams J, Stuck J (2012) 9. Nomenclature Committee - 2010-2012, Report of the AIPEA Nomenclature Committee for AIPEA Newsletter. Aipea Newsletter 44: 53-54.

[41] Hindman JR (1994) Vermiculite. In: Carr DD editor. Industrial Minerals and Rocks. Littleton, CO: Society for Mining, Metalurgy and Exploration, Inc.: pp. 1103-1111.

[42] Walker GF (1961) Vermiculites. In: Brown G (editor), The X-ray Identification and Crystal Structures of Clay Minerals. Mineralogical Society, London: pp. 297-324.

[43] Marcos C, Arango YC, Rodríguez I (2009) X-ray Diffraction Studies of the Thermal Behaviour of Commercial Vermiculites. Appl. clay sci. 42: 368-378.

[44] Walker GF (1951) Vermiculites and Some Related Mixed-Layer Minerals. In: Brindley GW, editor. X-ray Identification and Crystal Structures of Clay Minerals. Mineralogical Society, London: pp. 199-223.

[45] Midgley HG, Midgley CM (1960) The Mineralogy of Some Commercial Vermiculites. Clay miner. bull. 4: 142-150.

[46] Justo A, Maqueda C, Perez-Rodriguez JL, Morillo E (1989) Expansibility of Some Vermiculites. Appl. clay sci. 4: 509-519.

[47] Potter MJ (1997) Vermiculite. Am. ceram. soc. bull. 76: 135.

[48] Sanchez-Soto PJ, Ruiz Conde A, Aviles MA, Justo A, Pérez-Rodríguez JL (1995) Mechanochemical Effects on Vermiculite and its Influence on the Synthesis of Nitrogen Ceramics. In: Vicenzine P, editor. Ceramic Charting the Future. Techna Srl, Italia: pp. 1383- 1390.

[49] Ou CCY, Yang JC (1978). European Patent Application Eppl EP212930.

[50] Nelson LL (1988). European Patent Application EP 282928 A2.

[51] Balek V, Pérez-Rodríguez JL, Pérez-Maqueda LA, Šubrt J, Poyato J (2007) Thermal Behaviour of Ground Vermiculite. J. therm. anal. calorim. 88: 819-823.

[52] Peters D (1996) Ultrasound in Material Chemistry. J. mat. chem. 6: 1605-1618.

[53] Pérez-Maqueda LA, Caneo OB, Poyato J, Pérez-Rodríguez JL (2001) Preparation and Characterization of Micron and Submicron-Sized Vermiculite. Phys. chem. miner. 28: 61-66.

[54] Pérez-Rodríguez JL, Carrera F, Poyato J, Perez-Maqueda LA (2002) Sonication as a Tool for Preparing Nanometric Vermiculite Particles. Nanotechnology 13: 382-387. 
[55] Jiménez de Haro MC, Martínez Blanes JM, Poyato J, Pérez-Maqueda LA, Lerf A, PérezRodríguez JL (2004) Effects of Mechanical Treatment and Exchange Cation on the Microporozity of Vermiculite. J. phys. chem. solids 65: 435-439.

[56] Pérez-Maqueda LA, Jiménez de Haro MC, Poyato J, Pérez-Rodríguez JL (2004) Comparative Study of Ground and Sonicated Vermiculite. J. mat. sci. 39: 5347- 5351.

[57] Poyato J, Pérez-Rodríguez JL,Ramírez-Valle V, Lerf A, Wagner FE (2009) Sonication Induced Redox Reactions of the Ojén (Andalucía, Spain) Vermiculite. Ultrason. sonochem. 16: 570-576.

[58] Obut A, Girgin I (2002) Hydrogen Peroxide Exfoliation of Vermiculite and Phlogopite. Miner. eng. 15: 683-687.

[59] Üçgül E, Girgin I (2002) Chemical Exfoliation Characteristics of Karakoç Phlogopite in Hydrogen Peroxide Solution. Turk. j. chem. 26: 431-439.

[60] Weiss Z, Valášková M, Seidlerová J, Šupová-Křístková M, Šustai O, Matějka V, Čapková P (2006) Preparation of Vermiculite Nanoparticles using Thermal Hydrogen Peroxide Treatment. J. nanosci. nanotechnol. 6: 726-730.

[61] Matějka V, Šupová-Křístková M, Kratošová G, Valášková M (2006) Preparation of Mgvermiculite Nanoparticles using Potassium Persulfate Treatment. J. nanosci. nanotech. 6: 2484-2488.

[62] Kehal M, Laurence R, Duclaux L (2010) Characterization and Boron Adsorption Capacity of Vermiculite Modified by Thermal Shock or $\mathrm{H}_{2} \mathrm{O}_{2}$ Reaction and/or Sonication. Appl. clay. sci. 48: 561-568.

[63] Brown DR, Rhodes CN (1997) Brønsted and Lewis Acid Catalysis with Ion-Exchanged Clays. Catal. let. 45: 35-40.

[64] Schoonheydt RA, Johnston CT (2006) Surface and Interface Chemistry of Clay Minerals. In: Bergaya F, Theng BKG, Lagaly G, editors. Handbook of Clay Science Developments in Clay Science, Vol. 1, Elsevier Ltd.: pp. 87-113.

[65] Ayyappan S, Subbanna GN, Goplan RS, Rao CNR (1996) Nanoparticles of Nickel and Silver Produced by the Polyol Reduction of the Metal Salts Intercalated in Montmorillonite. Solid state ion. 84: 271-281.

[66] Aihara N, Torigoe E, Esumi K (1998) Preparation and Characterization of Gold and Silver Nanoparticles in Layered Laponite Suspensions. Langmuir 14: 4945-4949.

[67] Patakfalvi R, Oszkó A, Dékány I (2003) Synthesis and Characterization of Silver Nanoparticle/Kaolinite Composites. Colloid surf. A-physicochem. eng. asp. 220: 45-54.

[68] Patakfalvi R, Dékány I (2004) Synthesis and Intercalation of Silver Nanoparticles in Kaolinite/DMSO Complexes. Appl. clay sci. 25: 149-159.

[69] Praus P, Turicová M, Valášková M (2008) Study of Silver Adsorption on Montmorillonite. J. braz. chem. soc. 19: 549-556.

[70] Valášková M, Simha Martynková G, Lešková J, Čapková P, Klemm V, Rafaja D ( 2008) Silver Nanoparticles /Montmorillonite Composites Prepared using Nitrating Reagent at Water and Glycerol. J. nanosci. nanotechnol. 8: 3050-3058.

[71] Davies RL, Etris SF (1997) The Development and Functions of Silver in Water Purification and Disease Control. Catal. today 36: 107-114. 
[72] Feng QL, Wu J, Chen GQ, Cui FZ, Kim TN, Kim JO (2000) A Mechanic Study of the Antibacterial Effect of Silver Ions on Escherichia Coli and Staphylococcus Aureus. J. biomed. mater. res. part A 52: 662-668.

[73] Eberhart ME, Donovan MJ, Outlaw RA (1992) Ab Inito Calculations of Oxygen Diffusivity in Group-IB Transition Metals. Phys. rev. B 46: 12744-12747.

[74] Outlaw RA, Davidson MR (1994) Small Ultrahigh Vacuum Compatible Hyperthermal Oxygen Atom Generator. J. vac. sci. technol. A 12: 854-860.

[75] Elechiguerra JL, Burt JL, Morones JR, Camacho Bragado A, Gao X, Lara HH, Yaca Man MJ (2005) Interaction of Silver Nanoparticles with HIV-I. J. nanobiotechnol. 3: 6-16.

[76] Kiruba Daniel SCG, Tharmaraj V, Anitha Sironmani T, Pitchumani K (2010) Toxicity and Immunological Activity of Silver Nanoparticles. Appl. clay sci. 48: 547-551.

[77] Chimentão RJ, Kirm I, Medina F, Rodríguez X, Cesteros Y, Salagre P, Sueiras JE (2004) Different Morphologies of Silver Nanoparticles as Catalysts for the Selective Oxidation of Styrene in the Gas Phase. Chem. commun. 4: 846-847.

[78] Lofton C, Sigmund W (2005) Mechanisms Controlling Crystal Habits of Gold and Silver Colloids. Adv. funct. mater. 15: 1197-1208.

[79] Shao K, Yao J (2006) Preparation of Silver Nanoparticles via a Non-Template Method. Mater. lett. 60: 3826-3829.

[80] Zhang Z, Han M (2003) Template-Directed Growth from Small Clusters into Uniform Silver Nanoparticles. Chem. phys. lett. 374: 91-94.

[81] Esumi K, Suzuki A, Yamahira A, Torigoe K (2000) Role of Poly(amidoamine) Dendrimers for Preparing Nanoparticles of Gold Platinum and Silver. Langmuir 16: 2640-2680.

[82] Zhang Z, Zhang L, Wang S, Chen W, Lei Y (2001) A Convenient Route to Polyacrylonitrile/Silver Nanoparticle Composite by Simultaneous PolymerizationReduction Approach. Polymer 42: 8315-8318.

[83] Bajpai SK, Mohan YM, Bajpai M, Tankhiwale R, Thomas V (2007) Synthesis of Polymer Stabilized Silver and Gold Nanostructures. J. nanosci. nanotechnol. 7: 2994-3010.

[84] Mohan YM, Lee K, Premkumar T, Geckeler KE (2007) Hydrogel Networks as Nanoreactors: a Novel Approach to Silver Nanoparticles for Antibacterial Applications. Polymer 48: 158-164.

[85] Lee WF, Huang YC (2007) Swelling and Antibacterial Properties for the Superabsorbent Hydrogels Containing Silver Nanoparticles. J. appl. polym. sci. 106:1992-1999.

[86] Vimala K, Sivudu SK, Mohan MY, Sreedhar B, Raju MK (2009) Controlled Silver Nanoparticles Synthesis in Semihydrogel Networks of Poly(acrylamide) and Carbohydrates: a Rational Methodology for Antibacterial Application. Carbohydr. polym. 75: 463-471.

[87] Magaña SM, Quintana P, Aguilar DH, Toledo JA, Ángeles-Chávez C, Cortés MA, León L, Freile-Pelegrín Y, López T, Torres Sánchez RM (2008) Antibacterial Activity of Montmorillonites Modified with Silver. J. mol. catal. a-chem. 281: 192-199.

[88] Zhao D, Zhou J, Liu N (2006) Preparation and Characterization of Mingguang Palygorskite Supported with Silver and Copper for Antibacterial Behavior. Appl. clay sci. 33: 161-170. 
[89] Valášková M, Simha Martynková G, Matějka V, Barabaszová K, Plevová E, Měŕínská D (2009) Organovermiculite Nanofillers in Polypropylene. Appl. clay sci. 43: 108-112.

[90] Grim RE, Kulbicky G (1961) Montmorillonite: High Temperature Reactions and Classification. Am. miner. 46: 1329-1369.

[91] Ruitz-Hitzky E, van Meerbeek A (2006) Clay Mineral and Organoclay-Polymer Nanocomposites. In: Bergaya F, Theng BKG, Lagaly G, editors. Handbook of Clay Science Developments in Clay Science, Vol. 1, Elsevier Ltd. pp. 583-621.

[92] Lagaly G, Ogawa M, Dékány I (2006) Clay Mineral Organic Interactions. In: Bergaya F, Theng BKG, Lagaly G, editors. Handbook of Clay Science Developments in Clay Science, Vol. 1, Elsevier Ltd.: pp. 309-377.

[93] Tuney JJ, Detellier C (1996) Aluminosilicate Nanocomposites Materials. Poly(ethyleneglycol)-Kaolinite Intercalates. Chem. mat. 8: 927-35.

[94] Gilman JW, Jackson CL, Morgan AB, Harris R, Manias E, Giannelis EP, Wuthenow M, Hilton D, Phillips SH (2000) Flammability Properties of Polymer-Layered-Silicate Nanocomposites. Polypropylene and Polystyrene Nanocomposites. Chem. mat.12: 1866-1873.

[95] Osman MA, Rupp JEP, Suter UW (2005) Tensile Properties of Polyethylene/Layered Silicate Nanocomposites. Polymer 46: 1653-1660.

[96] Yuan Q, Misra RDK (2006) Impact Fracture Behavior of Clay-Reinforced Polypropylene Nanocomposites. Polymer 47: 4421-4433.

[97] Peneva Y, Tashev E, Minkova L (2006) Flammability, Microhardness and Transparency of Nanocomposites Based on Functionalized Polyethylenes. Eur. polym. j. 42: 22282235.

[98] Balazs AC, Singh Ch, Zhulina E (1998) Modeling the Interactions between Polymers and Clay Surfaces through Self-Consistent Field Theory. Macromolecules 31: 8370-8381.

[99] Rong M, Zhang M, Liu H, Zeng H (1999) Synthesis of Silver Nanoparticles and Their Self-Organization Behavior in Epoxy Resin. Polymer 40: 6169-6178.

[100] Liu X, Wu Q, Berglund L A (2002) Polymorphism in Polyamide 66/Clay Nanocomposites. Polymer 43: 4967-4972.

[101] Xu WB, Bao SP, Shen SJ, Hang GP, He, PS (2003) Curing Kinetics of Epoxy ResinImidazole-Organic Montmorillonite Nanocomposites Determined by Differential Scanning Calorimetry. J. appl. polym. sci. 88: 2932-2941.

[102] Yu ZZ, Yang M, Zhang Q, Zhao Ch, Mai YW (2003) Dispersion and Distribution of Organically Modified Montmorillonite in Nylon-66 Matrix. J. polym. sci. pt. b-polym. phys. 41: 1234-1243.

[103] Fornes TD, Paul DR (2003) Crystallization Behavior of Nylon 6 Nanocomposites. Polymer 44: 3945-3961.

[104] Das-Gupta DK (1994) Polyethylene: Structure, Morphology, Molecular Motion and Dielectric Behavior. IEEE Electr. insul. mag. 10: 5-15.

[105] Androsch R, Di Lorenzo ML, Schick Ch, Wunderlich B (2010) Mesophases in Polyethylene, Polypropylene, and Poly(1-butene). Polymer 51: 4639-4662. 
[106] Tjong SC, Meng, YZ (2003) Preparation and Characterization of Melt-Compounded Polyethylene/ Vermiculite Nanocomposites. J. polym. sci. pt. b-polym. phys. 41: 14761484 .

[107] Hotta S, Paul DR (2004) Nanocomposites Formed from Linear Low Density Polyethylene and Organoclays. Polymer 45: 7639-7654.

[108] Chrissopoulou K, Altintzi I, Anastasiadis SH, Giannelis EP, Pitsikalis M, Hadjichristidis N, Theophilou N (2005) Controlling the Miscibility of Polyethylene/ Layered Silicate Nanocomposites by Altering the Polymer/Surface Interactions. Polymer 46: 12440-12451.

[109] Tanniru M, Yuan Q, Misra RDK (2006) On Significant Retention of Impact Strength in Clay-Reinforced High-Density Polyethylene (HDPE) Nanocomposites. Polymer 47: 2133-2146.

[110] Tjong SC, Meng YZ, Xu J (2002) Preparation and Properties of Polyamide 6/Polypropylene-Vermiculite Nanocomposite/Polyamide 6 Alloys. J. appl. polym. sci. 86: 2330-2337.

[111] Tjong SC, Meng YZ (2003). Impact-Modified Polypropylene/Vermiculite Nanocomposites. J. polym. sci. pt. b-polym. phys. 41: 2332-2341.

[112] Shao W, Wang Q, Chen Y, Gu Y (2006) Preparation and Properties of Polypropylene/ Vermiculite Nanocomposite through Solid-State Shear Compounding (S3C) Method using Pan-Mill Equipment. Mater. manuf. process. 21: 173-179.

[113] Simha Martynková G., Barabaszová K, Valášková M (2007) Effect of Size and Preparation Method of Particles on Intercalation Ability of Vermiculite. Acta metall. slovaca 6: 275-279.

[114] Nam PH, Maiti P, Okamoto M, Kotaka T, Hasegawa N, Usuki A (2001] A Hierarchical Structure and Properties of Intercalated Polypropylene/Clay Nanocomposites. Polymer 42: 9633-9640.

[115] Gilman JW (1999) Flammability and Thermal Stability Studies of Polymer Layered Silicate (Clay) Nanocomposites. Appl. clay sci. 15: 31-49.

[116] Wang Z, Massam J, Pinnavaia TJ (2000) Epoxy - Clay Nanocomposites. In: Pinnavaia TJ, Beall GW, editors. Polymer-Clay Nanocomposites. New York: Wiley, New York: pp.127-148.

[117] Sinha Ray S, Bousmina M (2005) Biodegradable Polymers and their Layered Silicate Nanocomposites. In: Greening the 21st Century Materials World, Prog. mater. sci. 50: 962-1079.

[118] D'Souza NA (2004) Epoxy+clay nanocomposites. In: Nalwa HS, editor. Encyclopedia of Nanoscience and Nanotechnology, Vol.3 American Scientific Publishers, California: pp. 253-265.

[119] Giannelis EP (1996) Polymer Layered Silicate Nanocomposites. Adv. mater. 8: 29-35.

[120] Vaia RA, Giannelis EP (1997) Polymer Melt Intercalation in Organically-Modified Layered Silicates: Model Predications and Experiment. Macromolecules 30: 8000-8009.

[121] Vaia RA, Jandt KD, Kramer EJ, Giannelis EP (1995) Kinetics of Polymer Melt Intercalation. Macromolecules 28: 8080-8085. 
[122] Vaia RA, Jandt KD, Kramer EJ, Giannelis EP (1996) Microstructural Evolution of Melt Intercalated Polymer-Organically Modified Layered Silicates Nanocomposites. Chem. mater. 8: 2628-2635.

[123] LeBaron PC, Wang Z, Pinnavaia TJ (1999) Polymer-Layered Silicate Nanocomposites: An Overview. Appl. clay sci. 15: 11-29.

[124] Šupová M, Martynková GS, Barabaszová K (2011) Effect of Nanofillers Dispersion in Polymer Matrices: A Review. Sci. adv. mater. 3: 1-25.

[125] Zheng YA, Li P, Zhang JP,Wang AQ (2007) Study on Superabsorbent Composite XVI. Synthesis, Characterization and Swelling Behaviors of Poly(sodium acrylate)/ Vermiculite Superabsorbent Composites. Eur. polym. j. 43: 1691-1698.

[126] Wang W, Zhang J, Wang A (2009) Preparation and Swelling Properties of Superabsorbent Nanocomposites based on Natural Guar Gum and Organo-vermiculite. Appl.clay sci. 46: 21-26.

[127] Takahashi S, Goldberg HA, Feeney CA, Karim DP, Farrell M, O’Leary K, Paul DR (2003) Gas Barrier Properties of Butyl Rubber/Vermiculite Nanocomposite Coatings. Polymer 47: 3083-3093.

[128] De Rocher J, Gettelfinger BT, Wang J, Nuxoll EE, Cussler EL (2005) Barrier Membranes with Different Sizes of Aligned Flakes. J. memb. sci. 254: 21-30.

[129] Ravichandran J, Sivasankar B 1997 Properties and Catalytic Acivity of Acid Modified Montmorillonite and Vermiculite. Clays clay miner. 45: 854-858.

[130] Okada K, Arimitsu N, Kameshima Y, Nakajima A, Kenneth JD, MacKenzie KJD (2006) Solid Acidity of 2:1 type Clay Minerals Activated by Selective Leaching. Appl. clay sci. 31: 185-193.

[131] Xu S, Meng YZ, Li RKY, Xu Y, Rajulu A V (2003) Preparation and Properties of Poly(vinyl alcohol)-Vermiculite Nanocomposites. J. polym. sci. pt. b-polym. phys. 41: $749-755$.

[132] Dhamodharan R, Jeyaprakash JD, Samuel V, Rajeswari MK (2001) Intercalative Redox Polymerization and Characterization of Poly(4-vinylpyridine)-Vermiculite Nanocomposite. J. appl. polym. sci. 82: 555-561.

[133] Zhang J, Wang A (2007) Study on Superabsorbent Composites. IX: Synthesis, Characterization and Swelling Behaviors of Polyacrylamide/Clay Composites Based on Various Clays. React. funct. polym. 67: 737-745.

[134] Liu D, Du X, Meng Y (2006) Facile Synthesis of Exfoliated Polyaniline/Vermiculite Nanocomposites. Mater. lett. 60: 1847-1850.

[135] Swenson J, Schwartz GA, Bergman R, Howells WS (2003) Dynamics of Propylene Glycol and its Oligomers Confined in Clay. Eur. phys. j. e 12: 179-183.

[136] Schwartz GA, Bergman R, Mattsson J, and Swenson J (2003) Eur. phys. j. e 12: 113-116.

[137] da Silva DC, Skeff Neto K, Coaquira JAH, Araujo PP, Cintra DOS, Lima ECD, Guilherme LR, Mosiniewicz-Szablewska E, Morais PC (2010) Magnetic Characterization of Vermiculite-based Magnetic Nanocomposites. J.non-cryst. solids 356: 2574-2577.

[138] Zhang H, Yu J, Kuang D (2012) Effect of Expanded Vermiculite on Aging Properties of Bitumen. Constr. build. mater. 26: 244-248. 
[139] Du XS, Xiao M, Meng YZ, Hung TF, Rajulu AV, Tjong SC (2003) Synthesis of Poly(arylene disulfide)-Vermiculite Nanocomposites via in situ Ring-Opening Reaction of Cyclic Oligomers. Eur. polym. j. 39: 1735-1739.

[140] Yanga C, Liua P, Guoa J, Wang Y (2010) Polypyrrole/Vermiculite Nanocomposites via Self-Assembling and in Situ Chemical Oxidative Polymerization. Synth. met. 160: 592598.

[141] Xu J, Li RKY, Xu Y, Li L, Meng YZ (2005) Preparation of Poly(propylene carbonate)/Organo-Vermiculite Nanocomposites via Direct Melt Intercalation. Eur. polym. j. 41: 881-888.

[142] Armentano I, Dottori M, Fortunati M, Mattioli S, Kenny JM (2010) Biodegradable Polymer Matrix Nanocomposites for Tissue Engineering: A Review. Polym. degrad. stabil. 95: 2126-2146.

[143] Drumright RE, Gruber PR, Henton DE (2000) Polylactic Acid Technology. Adv. mater. 12: 1841-1846.

[144] Nam JY, Sinha Ray S, Okamoto M (2003) Crystallization Behavior and Morphology of Biodegradable Polylactide/Layered Silicate Nanocomposite. Macromolecules 36:7126 7131.

[145] Paul MA, Alexandre M, Degee P, Calberg C, Jerome R, Drbois P (2003) Exfoliated Polylactide/Clay Nanocomposites by in situ Coordinationinsertion Polymerization. Macromol. rapid commun. 24: 561-566.

[146] Ogata N, Jimenez G, Kawai H, Ogihara T (1997) Structure and Thermal/Mechanical Properties of Poly(L-lactide)-Clay Blend. J. polym. sci. pt. b-polym. phys. 35: 389-396.

[147] Xu H, Bai Y, Mao Z (2011) Preparation of PLLA-co-bis A ER/VMT Nanocomposites by In-Situ Polymerization Process. The open mat. sci. j. 5: 56-60.

[148] Zhang K, Xu J, Wang KY, Cheng V, Wang V, Liu V (2009) Preparation and Characterization of Chitosan Nanocomposites with Vermiculite of Different Modification. Polym. degrad. stabil. 94: 2121-2127. 